\title{
Methane and carbon dioxide fluxes and their regional scalability for the European Arctic wetlands during the MAMM project in summer 2012
}

\author{
S. J. O'Shea ${ }^{1}$, G. Allen ${ }^{1}$, M. W. Gallagher ${ }^{1}$, K. Bower ${ }^{1}$, S. M. Illingworth ${ }^{1, *}$, J. B. A. Muller ${ }^{1}$, B. T. Jones ${ }^{1}$, \\ C. J. Percival ${ }^{1}$, S. J-B. Bauguitte ${ }^{2}$, M. Cain ${ }^{3}$, N. Warwick ${ }^{10,3}$, A. Quiquet $^{3}$, U. Skiba ${ }^{4}$, J. Drewer ${ }^{4}$, K. Dinsmore ${ }^{4}$, \\ E. G. Nisbet ${ }^{5}$, D. Lowry ${ }^{5}$, R. E. Fisher ${ }^{5}$, J. L. France ${ }^{5, * *}$, M. Aurela ${ }^{6}$, A. Lohila ${ }^{6}$, G. Hayman ${ }^{7}$, C. George ${ }^{7}$, \\ D. B. Clark ${ }^{7}$, A. J. Manning ${ }^{8}$, A. D. Friend ${ }^{9}$, and J. Pyle ${ }^{10,3}$ \\ ${ }^{1}$ School of Earth, Atmospheric and Environmental Sciences, University of Manchester, Oxford Road, \\ Manchester, M13 9PL, UK \\ ${ }^{2}$ Facility for Airborne Atmospheric Measurements (FAAM), Building 125, Cranfield University, Cranfield, \\ Bedford, MK43 0AL, UK \\ ${ }^{3}$ Centre for Atmospheric Science, University of Cambridge, Cambridge CB2 1EW, UK \\ ${ }^{4}$ Centre for Ecology and Hydrology, Bush Estate, Penicuik, Midlothian, EH26 0QB, UK \\ ${ }^{5}$ Department of Earth Sciences, Royal Holloway, University of London, Egham TW20 0EX, UK \\ ${ }^{6}$ Climate Change Research, Finnish Meteorological Institute, P.O. Box 503, 00101, Helsinki, Finland \\ ${ }^{7}$ Centre for Ecology and Hydrology, Maclean Building, Crowmarsh Gifford, Wallingford, OX10 8BB, UK \\ ${ }^{8}$ UK Meteorological Office, Fitzroy Rd, Exeter, UK \\ ${ }^{9}$ Department of Geography, Downing Place, Cambridge CB2 3EN, UK \\ ${ }^{10}$ National Centre for Atmospheric Science, UK \\ *now at: School of Research, Enterprise \& Innovation, Manchester Metropolitan University, Chester Street, \\ Manchester, M1 5GD, UK \\ ** now at: School of Environmental Sciences, University of East Anglia, Norwich, NR4 7TJ, UK
}

Correspondence to: S. J. O’Shea (sebastian.oshea@manchester.ac.uk)

Received: 7 February 2014 - Published in Atmos. Chem. Phys. Discuss.: 31 March 2014

Revised: 28 August 2014 - Accepted: 31 October 2014 - Published: 10 December 2014

\begin{abstract}
Airborne and ground-based measurements of methane $\left(\mathrm{CH}_{4}\right)$, carbon dioxide $\left(\mathrm{CO}_{2}\right)$ and boundary layer thermodynamics were recorded over the Fennoscandian landscape $\left(67-69.5^{\circ} \mathrm{N}, 20-28^{\circ} \mathrm{E}\right)$ in July 2012 as part of the MAMM (Methane and other greenhouse gases in the Arctic: Measurements, process studies and Modelling) field campaign. Employing these airborne measurements and a simple boundary layer box model, net regional-scale $(\sim 100 \mathrm{~km})$ fluxes were calculated to be $1.2 \pm 0.5 \mathrm{mg} \mathrm{CH}_{4} \mathrm{~h}^{-1} \mathrm{~m}^{-2}$ and $-350 \pm 143 \mathrm{mg} \mathrm{CO}_{2} \mathrm{~h}^{-1} \mathrm{~m}^{-2}$. These airborne fluxes were found to be relatively consistent with seasonally averaged surface chamber $\left(1.3 \pm 1.0 \mathrm{mg} \mathrm{CH}_{4} \mathrm{~h}^{-1} \mathrm{~m}^{-2}\right)$ and eddy covariance $\left(1.3 \pm 0.3 \mathrm{mg} \mathrm{CH}_{4} \mathrm{~h}^{-1} \mathrm{~m}^{-2}\right.$ and $-309 \pm 306 \mathrm{mg} \mathrm{CO}_{2} \mathrm{~h}^{-1} \mathrm{~m}^{-2}$ ) flux measurements in the
\end{abstract}

local area. The internal consistency of the aircraft-derived fluxes across a wide swath of Fennoscandia coupled with an excellent statistical comparison with local seasonally averaged ground-based measurements demonstrates the potential scalability of such localised measurements to regional-scale representativeness. Comparisons were also made to longerterm regional $\mathrm{CH}_{4}$ climatologies from the JULES (Joint UK Land Environment Simulator) and HYBRID8 land surface models within the area of the MAMM campaign. The average hourly emission flux output for the summer period (July-August) for the year 2012 was $0.084 \mathrm{mg} \mathrm{CH}_{4} \mathrm{~h}^{-1} \mathrm{~m}^{-2}$ (minimum 0.0 and maximum $0.21 \mathrm{mg} \mathrm{CH}_{4} \mathrm{~h}^{-1} \mathrm{~m}^{-2}$ ) for the JULES model and $0.088 \mathrm{mg} \mathrm{CH}_{4} \mathrm{~h}^{-1} \mathrm{~m}^{-2}$ (minimum 0.0008 and maximum $1.53 \mathrm{mg} \mathrm{CH}_{4} \mathrm{~h}^{-1} \mathrm{~m}^{-2}$ ) for HYBRID8. 
Based on these observations both models were found to significantly underestimate the $\mathrm{CH}_{4}$ emission flux in this region, which was linked to the under-prediction of the wetland extents generated by the models.

\section{Introduction}

Temperatures at high northern latitudes have been observed to be increasing at a rate of twice the global average over the past two decades (Forster and Ramaswamy, 2007). It has been suggested that this rise will continue (Parmentier et al., 2013). This is likely to have significant consequences for natural greenhouse gas emissions in the region, which contain potentially large sources that are known to be highly sensitive to changes in temperature, such as the boreal wetlands and the reservoirs of carbon that are sequestered in permafrost and as methane hydrates (Smith et al., 2004; Zimov et al., 2006a, b; Ping et al., 2008). As well as contributing to radiative forcing, such emissions have the potential to significantly perturb atmospheric chemistry, including oxidant capacity (Isaksen et al., 2011). Palaeo-records indicate that strong positive feedbacks exist between climate and greenhouse gas emissions in the region, whereby warming causes enhanced emissions that in turn lead to further warming (Walter et al., 2007; Nisbet and Chappellaz, 2009). Recent studies have already reported newly identified or growing $\mathrm{CH}_{4}$ emissions from some of these carbon reservoirs (Westbrook et al., 2009; Shakhova et al., 2010; Kort et al., 2012; Anthony et al., 2012).

Wetland regions are the single largest source of atmospheric $\mathrm{CH}_{4}$, accounting for approximately a third of total global $\mathrm{CH}_{4}$ emissions equivalent to $142-208 \mathrm{Tg} \mathrm{yr}^{-1}$ (Kirschke et al., 2013), for which Boreal and Arctic regions make a significant contribution (approximately $25 \%$; Smith et al., 2004; Zhuang et al., 2006). Much of the remainder is currently suggested to originate from tropical wetlands (Bridgham et al., 2013). Biogenic $\mathrm{CH}_{4}$ is produced in anoxic soils through the decomposition of organic matter by methanogenic bacteria (Bridgham et al., 2013). Emission rates by this process are dependent on soil moisture, temperature and the availability of organic matter (Pelletier et al., 2007; Strom and Christensen, 2007). Much of this $\mathrm{CH}_{4}$ does not reach the atmosphere due to consumption that occurs in oxic soil regions by methanotrophic bacteria (O'Connor et al., 2010; Parmentier et al., 2011). As a result of these competing environment-dependant factors, emissions show a large degree of spatial and temporal variability (Zhuang et al., 2006; Pickett-Heaps et al., 2011).

$\mathrm{CO}_{2}$ exchange between the surface and the atmosphere in these regions displays a similar degree of complexity. It is governed by the interplay between release of $\mathrm{CO}_{2}$ through respiration and uptake by photosynthesis. At high latitudes, as temperatures rise and the ground thaw reaches greater soil depths, more organic carbon becomes available for decomposition, potentially liberating large carbon reservoirs to the atmosphere (Oelke et al., 2004). However, a simultaneous increase in plant production and biomass may also occur during the growing season. Rapid warming at high latitudes is increasing both plant growth and soil decomposition, making it difficult to determine the overall impact a warmer climate has on the total net carbon budget of Arctic and Boreal regions (Zhuang et al., 2006; Davidson and Janssens, 2006; Sitch et al., 2007; Schuur et al., 2009).

Previously, Arctic wetland emissions have been determined by up-scaling surface chamber and eddy covariance flux measurements (Pelletier et al., 2007) or by process-based and inverse models (Petrescu et al. 2010; Pickett-Heaps et al., 2011; Wania et al., 2010; Bousquet et al., 2011). However, due to the heterogeneous nature of wetlands, uncertainties exist when multiple studies are synthesised to determine net emissions for large areas (Christensen et al., 2007). Currently, there is a lack of flux measurements at the same spatial scale as the resolution of global land surface models (typically $0.5^{\circ}$ ), which has been identified as a key reason why models are not able to confidently simulate the wetland $\mathrm{CH}_{4}$ flux (Melton et al., 2013). Airborne measurements have been shown to be a powerful tool in reducing these uncertainties (Desjardins et al., 1997; Miller et al., 2007; Peischl et al., 2012), where the greater spatial coverage afforded may be an advantage over ground-based measurements under appropriate conditions, especially when testing the scalability of fluxes derived for local scales across wider areas.

Ground-based $\mathrm{CH}_{4}$ flux measurements have now been made for multiple years in several wetland locations within northern Fennoscandia, these include the Stordalen wetlands, in sub-arctic Sweden $\left(68.33^{\circ} \mathrm{N}, 19.05^{\circ} \mathrm{E}\right.$; Christensen et al., 2012), and both Kaamanen $\left(69.1^{\circ} \mathrm{N}, 27.2^{\circ} \mathrm{E}\right.$; Maanavilja et al., 2011) and Lompolojänkkä $\left(68.0^{\circ} \mathrm{N}, 24.2^{\circ} \mathrm{E}\right.$; Aurela et al., 2009) in Finland. Stordalen summer $\mathrm{CH}_{4}$ emissions have been reported as $4.7 \mathrm{mg} \mathrm{CH}_{4} \mathrm{~m}^{-2} \mathrm{~h}^{-1}$ (2004-2006) and $6.2 \pm 2.6 \mathrm{mg} \mathrm{CH}_{4} \mathrm{~m}^{-2} \mathrm{~h}^{-1}$ (2006 and 2007) (Petrescu et al., 2008; Jackowicz-Korczynski et al., 2010). Mean July $\mathrm{CO}_{2}$ fluxes are $-1152 \mathrm{mg} \mathrm{CO}_{2} \mathrm{~m}^{-2} \mathrm{~h}^{-1},-576 \mathrm{mg} \mathrm{CO}_{2} \mathrm{~m}^{-2} \mathrm{~h}^{-1}$ and $-504 \mathrm{mg} \mathrm{CO}_{2} \mathrm{~m}^{-2} \mathrm{~h}^{-1}$ for Lompolojänkkä, Kaamanen and Siikaneva, respectively (Aurela et al., 2009).

This paper uses in situ measurements collected on board the UK's Facility for Airborne Atmospheric Measurements (FAAM) BAe-146 research aircraft to quantify greenhouse gas net fluxes from the Fennoscandian wetlands during a dedicated case study. A simple boundary layer mass budget approach (described in Sect. 3.1) is employed to derive regional fluxes using the aircraft observations under pseudo-stationary boundary layer flow assumptions (Sect. 4.1). This estimate is then compared to smaller footprint ground-based eddy covariance and chamber measurements within the aircraft's sampling footprint that were made over much of summer 2012 to address scalability and spatiotemporal heterogeneity (Sect. 4.3). Finally, the regional-scale 
aircraft-derived flux is used to assess the skill of two land surface models (Sect. 4.4).

\section{Methods}

The measurements reported in this paper were collected as part of the MAMM (Methane and other greenhouse gases in the Arctic: Measurements, process studies and Modelling, http://arp.arctic.ac.uk/projects/ methane-and-other-greenhouse-gases-arctic-measurem/) project. The aim of the MAMM project is to quantify greenhouse gas fluxes at high northern latitudes using a combination of measurement, process and modelling studies. As part of this project, sorties were performed from Kiruna, Sweden, by the FAAM BAe-146 research aircraft during July 2012 (six flights), August 2013 (nine flights), September 2013 (seven flights) and July 2014 (eight flights). This flight has been chosen for this case study due to the favourable meteorological and flight conditions for applying a mass budget approach (Sect. 3.1) to derive fluxes (Sect. 4.1). The MAMM campaign is ongoing at the time of writing and we anticipate that a seasonal analysis will be addressed in the future.

\subsection{FAAM BAe-146 research aircraft}

$\mathrm{CO}_{2}$ and $\mathrm{CH}_{4}$ dry air mole fractions were determined through cavity-enhanced absorption spectroscopy on board the FAAM BAe-146 (Model RMT-200, Los Gatos Research Inc., USA). In-flight $\mathrm{CO}_{2}$ uncertainty was calculated as $\pm 0.17 \mathrm{ppm}$; typical $1 \mathrm{~Hz}$ precision is $\pm 0.70 \mathrm{ppm}$ (all precisions are $1 \sigma) . \mathrm{CH}_{4}$ uncertainty is calculated at $\pm 1.31 \mathrm{ppb}$; $1 \mathrm{~Hz}$ precision is $\pm 2.37 \mathrm{ppb}$ (for a detailed description of this system see O'Shea et al., 2013b). Separate measurements of $\mathrm{CO}_{2}$ and $\mathrm{CH}_{4}$ were made by analysing whole-air samples. These were collected in stainless steel flasks (for a description see Lewis et al., 2013), and analysed postflight in the laboratory using cavity-ring down spectroscopy (Model G1301, Picarro Inc., USA). Uncertainty is estimated at $\pm 0.5 \mathrm{ppb}$ and $\pm 0.1 \mathrm{ppm}$ for $\mathrm{CH}_{4}$ and $\mathrm{CO}_{2}$, respectively. During the MAMM flights the mean bias of the wholeair samples (400 samples) relative to the in situ measurements was $0.16( \pm 0.46$ at $1 \sigma)$ ppm for $\mathrm{CO}_{2}$ and $-0.5( \pm 4.6$ at $1 \sigma) \mathrm{ppb}$ for $\mathrm{CH}_{4}$. Flask samples were also analysed for $\delta^{13} \mathrm{C}$ isotopic ratios of $\mathrm{CO}_{2}$ and $\mathrm{CH}_{4}$, using continuous-flow gas chromatography / isotope-ratio mass spectrometry, with a precision of $0.1 \%$ (Fisher et al., 2006).

A range of other chemical, tracer and thermodynamic parameters were measured simultaneously on board the FAAM BAe-146; these include pressure, temperature and the 3D wind vector with an estimated uncertainty of $0.3 \mathrm{hPa}$, $0.1 \mathrm{~K}$ and $0.2 \mathrm{~m} \mathrm{~s}^{-1}$, respectively (Allen et al., 2011). Measurements of carbon monoxide $(\mathrm{CO})$ and hydrogen cyanide $(\mathrm{HCN})$ are used here to identify air masses that have been strongly influenced by either biomass burning or anthropogenic activity using an enhancement-over-backgroundthreshold technique described by O'Shea et al. (2013a), as such air masses would bias the calculation of the biogenic flux. Mole fractions of $\mathrm{CO}$ were determined through vacuum ultraviolet fast-fluorescence spectrometry, with an uncertainty of $2 \%$ (AL5002, Aerolaser GmbH, Germany; Gerbig et al., 1999). In situ HCN measurements were made using a chemical ionisation mass spectrometer, with an uncertainty of $10 \%$ (Le Breton et al., 2013).

\subsection{Surface measurements}

$\mathrm{CH}_{4}$ and $\mathrm{CO}_{2}$ eddy covariance and chamber flux measurements were made in Sodankylä, Finland, from 1 July 2012 to 15 August 2012. The eddy covariance system used included a USA-1 (METEK GmbH, Germany) three-axis sonic anemometer/thermometer, a RMT-200 (Los Gatos Research, Inc., USA) $\mathrm{CH}_{4}$ analyzer and a LI-7200 (Li-Cor, Inc., USA) $\mathrm{CO}_{2} / \mathrm{H}_{2} \mathrm{O}$ gas analyzer. The measurement height was $6 \mathrm{~m}$ a.g.l. (above ground level). The length of the inlet tubes for both gases was $8 \mathrm{~m}$ for $\mathrm{CH}_{4}$ and $1 \mathrm{~m}$ for $\mathrm{CO}_{2}$, with flow rates of 15 and $20 \mathrm{Lmin}^{-1}$, respectively. For more details of the eddy covariance measurement system, see Aurela et al. (2009).

Half-hour flux values were calculated using standard eddy covariance methods. The original $10 \mathrm{~Hz}$ data were blockaveraged, and a double rotation of the coordinate system was performed (McMillen, 1988). The time lag between the anemometer and gas analyzer signals, resulting from the transport through the inlet tube, was taken into account in the on-line calculations. An air density correction related to the latent heat fluxes was conducted according to Webb et al. (1980). Corrections for the systematic high-frequency flux loss owing to the imperfect properties and set-up of the sensors (i.e. insufficient response time, sensor separation, damping of the signal in the tubing and averaging over the measurement paths) were carried out off-line using transfer functions with empirically determined time constants (Aubinet et al., 2000). All data with wind directions from sector 240 to $290^{\circ}$ were discarded due to insufficient fetch. Some data were also discarded due to instrument failures during weak turbulence (friction velocity $<0.1 \mathrm{~m} \mathrm{~s}^{-1}$ ). $\mathrm{CO}_{2}$ fluxes during the period 14 July 2012 to 1 August 2012 are missing due to instrumental problems.

Fluxes of $\mathrm{CH}_{4}$ were also measured using the static chamber method, as follows. These were positioned to cover a range of vegetation types and water saturations that can be broadly classified into either those situated in wetlands (39 chambers) and those in the forest (21 chambers). Shallow frames were installed the day before first sampling to a depth of $\sim 10 \mathrm{~cm}$, and remained in situ for the duration of the study period; fluxes calculated from the first sampling were not significantly different from subsequent sampling occasions suggesting that the short settling period after frame installation 
had no effect. Fluxes were measured at $\sim 2$-day intervals between 12 July and 2 August. For measurements, chamber lids were attached to the frames and internal air samples were collected into vials four times over a 45 min incubation period. Samples were analyzed by gas chromatography and fluxes calculated using GCFlux, version 2. Reported $\mathrm{CH}_{4}$ fluxes correlate to the best-fit model for individual chambers (either linear or asymptotic) (for a detailed description of this approach see Levy et al., 2011, 2012). Fluxes of $\mathrm{N}_{2} \mathrm{O}$ and $\mathrm{CO}_{2}$ were also measured by the static chamber method. However, since static-chamber-measured $\mathrm{CO}_{2}$ fluxes are only a measure of the ecosystem respiration inside the chambers and do not include uptake by all plants, they cannot be directly compared with the aircraft-derived flux estimates; this will be presented in a separate study.

\subsection{Methane emission models}

In Sect. 4.4, we assess the skill of two land surface models: the Joint UK Land Earth Simulator (JULES; Best et al., 2011; Clark et al., 2011) and HYBRID8 (Friend, 2010). The JULES model contains a $\mathrm{CH}_{4}$ wetland emission parameterisation, developed and tested by Gedney et al. (2004) for use at large spatial scales. The wetland parameterisation is coupled to the large-scale hydrology scheme of Gedney and Cox (2003), which predicts the distribution of sub-grid-scale water table depth and wetland fraction $\left(f_{\mathrm{w}}\right)$ from the overall soil moisture content and the sub-grid-scale topography using the approach of Beven and Kirby (1979). The $\mathrm{CH}_{4}$ flux from wetlands, $F_{\mathrm{w}}\left(\mathrm{CH}_{4}\right)$, is parameterised as a function of temperature, wetland fraction and substrate availability, as follows:

$$
F_{\mathrm{w}}\left(\mathrm{CH}_{4}\right)=f_{\mathrm{w}} k\left(\mathrm{CH}_{4}\right) C_{\mathrm{s}} Q_{10}\left(T_{\text {soil }}\right)^{\left(T_{\text {soil }}-T_{0}\right) / 10},
$$

where $T_{\text {soil }}$ is the soil temperature (in $\mathrm{K}$ ) averaged over the top $10 \mathrm{~cm}$ and $k\left(\mathrm{CH}_{4}\right)$ is a global constant which is calibrated to give the required global $\mathrm{CH}_{4}$ flux. The $Q_{10}$ is a temperature coefficient to account for the temperature dependency of the flux. Soil carbon content $\left(\mathrm{C}_{\mathrm{s}}\right)$ was used for substrate availability. The default parameter values chosen were $k\left(\mathrm{CH}_{4}\right)=7.4 \times 10^{-12} \mathrm{~kg} \mathrm{~m}^{-2} \mathrm{~s}^{-1}, T_{0}=273.15 \mathrm{~K}$ and $Q_{10}\left(T_{0}\right)=3.7$ (Clark et al., 2011).

The surface physics of the HYBRID8 model are based on the NASA-Goddard Institute for Space Studies (GISS) ModelE land surface component (Schmidt et al., 2006). This model contains a canopy representation that has a mechanistic canopy conductance response to various environmental factors (light, temperature, humidity, $\mathrm{CO}_{2}$ and canopy height), which has been tested and calibrated using eddy covariance flux measurements (Friend and Kiang, 2005). Recently, a TOPMODEL (a TOPography based hydrological MODEL) approach has been implemented to model the hydrology following Niu et al. (2005). Very similar to the implementation in the JULES land surface model, the TOPMODEL hydrological module in HYBRID8 uses a topo- graphical index and interactively computes the wetland fraction in each grid box $\left(f_{\mathrm{w}}\right)$, and only saturated soils (determined by $f_{\mathrm{w}}$ ) contribute to $\mathrm{CH}_{4}$ emissions. The fluxes of $\mathrm{CH}_{4}$ are also parameterised in a very similar way in HYBRID8 as in JULES. The governing equation for $\mathrm{CH}_{4}$ production at depth $z$ is

$P_{\mathrm{W}}\left(\mathrm{CH}_{4}\right)=k\left(\mathrm{CH}_{4}\right) \operatorname{Fps}(z) C_{\mathrm{som}}(z) Q_{10}^{\left(T(z)-T_{0}\right) / 10}$,

where $k\left(\mathrm{CH}_{4}\right)$ is the baseline production rate, $\operatorname{Fps}(z)$ is the total pore space fraction in a specific layer (a function of soil texture), $C_{\text {som }}(z)$ is the soil organic matter at the depth $z$, and $T(z)$ is the soil temperature. For this study, the following representative parameters were chosen: $k\left(\mathrm{CH}_{4}\right)=$ $1.3 \times 10^{-11} \mathrm{~kg} \mathrm{~m}^{-2} \mathrm{~s}^{-1}, Q_{10}=3$ and $T_{0}=22^{\circ} \mathrm{C}$. The $\mathrm{CH}_{4}$ produced is then transported to adjacent layers via diffusivity, eventually reaching the atmosphere.

\section{Experiment and analysis methodology}

The following section describes the 22 July 2012 flight that was used to determine regional-scale fluxes using a mass balance approach.

\subsection{Aircraft mass balance}

Mass budget approaches have been employed on several occasions to derive regional-scale $(>1 \mathrm{~km})$ fluxes of trace species (White et al., 1976; Gallagher et al., 1994; Choularton et al., 1995; Wratt et al., 2001; Mays et al., 2009; O'Shea et al., 2014). Observations are typically made in a background location and then down-wind of a source region to determine the net enhancement due to this region. The mass budget approach used in this study is most applicable when measurements are collected parallel to the prevailing wind vector. If it can be assumed that the non-reactive tracer species, $S$, is well mixed from the surface up to the top of the planetary boundary layer (PBL), $Z_{1}$, and that entrainment into (and detrainment from) the PBL can be neglected, then the net flux of $S$ can be determined by

flux $=\frac{\bar{U}}{\cos \phi} \frac{\Delta S}{\Delta x} \int_{0}^{Z_{1}} n \mathrm{~d} z$,

where $\bar{U}\left(\mathrm{~m} \mathrm{~s}^{-1}\right)$ is the mean wind speed, and $n$ (molecules $\mathrm{m}^{-3}$ ) is the atmospheric number density, which is integrated from the surface to the top of the boundary layer $(m)$. The $\Delta S$ (molecules molecules ${ }^{-1}$ ) term is the enhancement in species $S$ along the transect $x$ of increment $\Delta x(m)$. The angle $\phi$ is between the mean wind vector and transect $x$; see Hiller et al. (2014) for further details on the origin of Eq. (3). In addition to a well-mixed PBL, several other requirements regarding the PBL structure have to be met for this simple model to be applicable. First, a single wind vector needs to be assumed. Changes in either the wind speed or 
direction will add uncertainty in the calculated flux. Second, it is assumed that any surface emission is immediately mixed throughout the PBL column. Third, the PBL height should not vary significantly while measurements are collected and a strong capping inversion is needed to prevent significant exchange with the free troposphere. We examine the uncertainty resulting from each of these assumptions in Sect. 4.

\subsection{Flight sampling and study area}

On the 22 July 2012 the FAAM BAe-146 surveyed the northern Fennoscandian landscape in order to quantify emissions from the wetlands in the region. Four large transects $(\sim 340 \mathrm{~km})$ were performed within the PBL: two eastwest (east to west transect 10:42 to 11:46 GMT (Greenwich mean time); west to east $15: 26$ to $16: 04 \mathrm{GMT}$ ) and two north-south. Figure 1a shows the geographic coverage of this flight along with the location of waypoints: Kiruna $\left(67.9^{\circ} \mathrm{N}, 20.2^{\circ} \mathrm{E}\right)$, Sodankylä $\left(67.4^{\circ} \mathrm{N}, 26.6^{\circ} \mathrm{E}\right)$ and Kaamanen $\left(69.1^{\circ} \mathrm{N}, 27.2^{\circ} \mathrm{E}\right)$. Figure $2 \mathrm{a}$ and $\mathrm{b}$ show observations of $\mathrm{CH}_{4}$ and $\mathrm{CO}_{2}$ collected during longitudinal transects parallel to the prevailing wind. Figure $2 \mathrm{c}$ shows the FAAM BAe-146's altitude when these measurements were collected, which was varied during transects in order to characterise both the vertical and horizontal gradients of $\mathrm{CH}_{4}$ and $\mathrm{CO}_{2}$.

To show the prevalent vegetation and land use types within the region, the flight track is also shown overlaying the land classification (Fig. 1c; CORINE land cover 2006; http://www.eea.europa.eu/data-and-maps/data/ corine-land-cover-2006-raster). As seen, the sampling domain is largely characterised by coniferous forests (33\%; dark green Fig. 1c), peat bogs (23\%; blue Fig. 1c) and mixed forests (16\%; green Fig. 1c).

\subsection{Meteorology overview}

Meteorological conditions on the 22 July 2012 were characterised by low pressure centred over the Barents Sea to the north of the FAAM BAe-146's sampling domain in this case study. This resulted in a consistent westerly airflow across northern Scandinavia and shallow cumulus clouds $(\sim 2 / 8$ cover). Surface temperature was $\sim 17^{\circ} \mathrm{C}$, as confirmed by infrared radiometers on the aircraft. The synoptic airflow is illustrated in Fig. 1b, which shows HYSPLIT (Hybrid Single Particle Lagrangian Integrated Trajectory Model; described by Draxler and Rolph, 2003) back trajectories calculated along the FAAM BAe-146's flight track when it was within the PBL (below $1500 \mathrm{~m}$ altitude). The majority of the air mass sampled by the FAAM BAe-146 on 22 July 2012 spent the previous 5 days at a low level (below $2000 \mathrm{~m}$ ) within the Arctic region and over the Arctic Ocean. During the FAAM flight, in situ measurements also showed winds to be consistently westerly, the mean wind bearing and speed within the boundary layer was $260(37 \text { at } 1 \sigma)^{\circ}$ and $6(2$ at $1 \sigma) \mathrm{ms}^{-1}$, respectively.
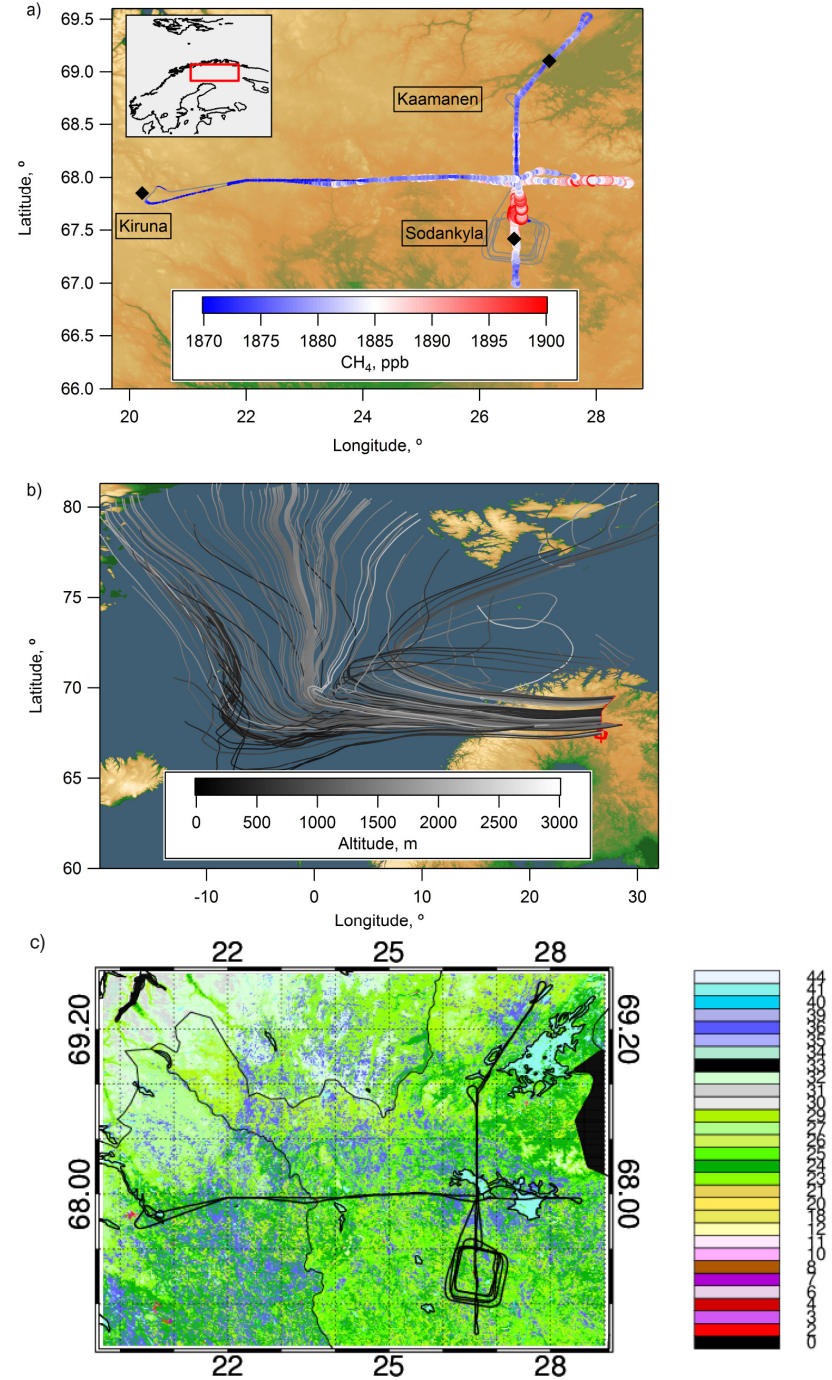

Figure 1. (a) FAAM BAe-146 flight track for flight B720 (22 July 2012). Observations of $\mathrm{CH}_{4}$ in the PBL are coloured according to the legend. Black diamonds mark Kiruna, Sodankylä and Kaamanen. (b) Five-day HYSPLIT back trajectories that were started every minute along the FAAM BAe-146's flight track when it was within the PBL. (c) Flight track where the surface is coloured using the land use type (CORINE land cover 2006). Numbers correspond to land types given in Table 1.

Deep vertical profiles of potential temperature (derived here from in situ measurements of pressure and temperature) from the FAAM BAe-146, performed over Sodankylä (Fig. 3) at 01:00 and 15:00 GMT and from the two dropsondes released, show a clear capping inversion was present over the area during the flight (Fig. 3). Over the run in question, the surface topography was very flat, 400-500 $\mathrm{m}$ a.m.s.1. (above mean sea level) and the infrared emissivity varied little ( 0.98; see Allen et al., 2014). Therefore, in the absence of significant synoptic meteorological changes, which were not observed in reanalyses for the area, it is expected 

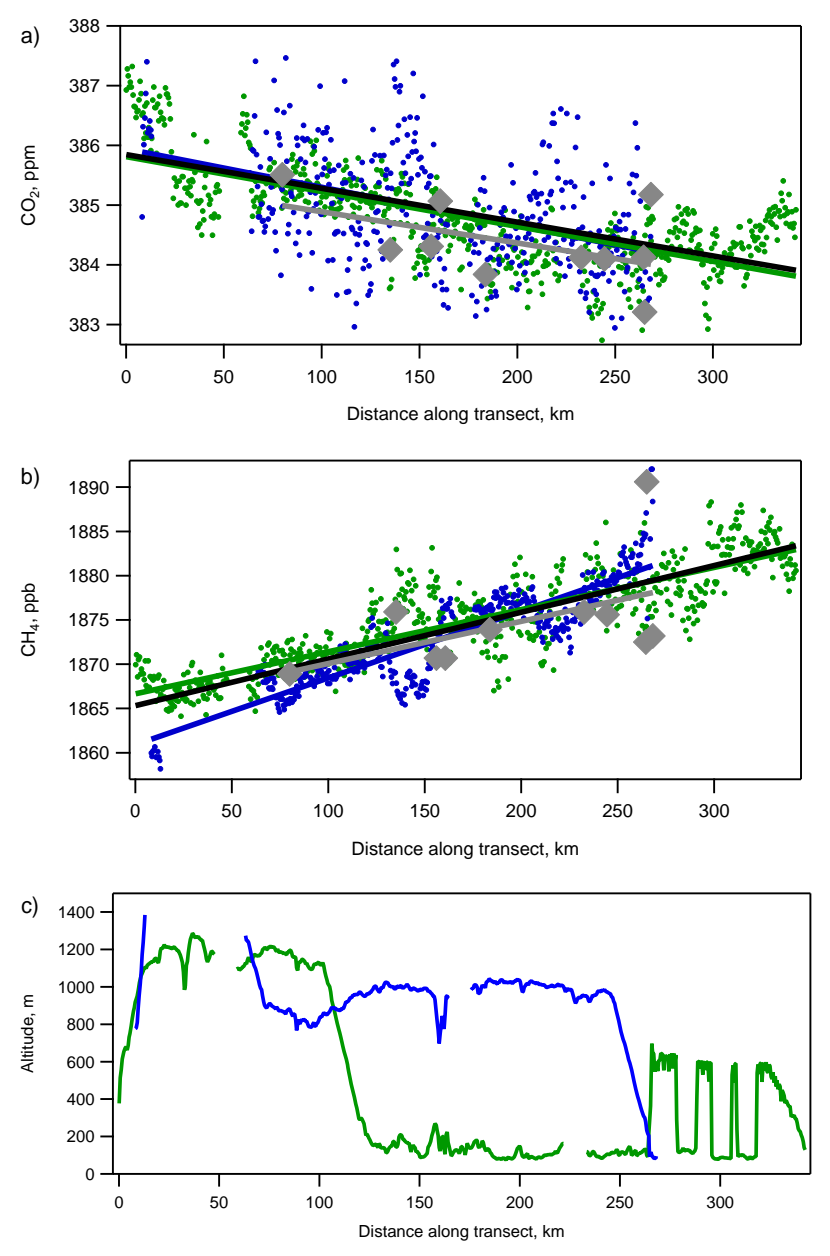

— Both transects $\bullet$ Eastward transect $\bullet$ Westward transect $\diamond$ Whole air samples

Figure 2. (a) $\mathrm{CH}_{4}$ and (b) $\mathrm{CO}_{2}$ observations along a flight transect, which was aligned with the prevailing wind direction. The origin is $20^{\circ} \mathrm{E}, 68^{\circ} \mathrm{N}$ and the transect extends in an eastward direction. The gradients observed in both species were used to determine a net emission flux for the region using Eq. (3). (c) The aircraft's altitude when measurements shown in (b) and (c) were collected.

that the PBL depth was relatively uniform over the time and scale of the sampling in question. This is further examined in Sect. 4.1.

\section{Results and discussion}

On the 22 July 2012, consistent linear gradients were observed in both $\mathrm{CH}_{4}$ and $\mathrm{CO}_{2}$ along the longitudinal transects (Fig. 1), performed parallel to the prevailing wind. $\mathrm{CH}_{4}$ was found to be approximately $20 \mathrm{ppb}$ higher at the eastern boundary compared to the western, while $\mathrm{CO}_{2}$ decreased by several ppm over the same interval. No clear latitudinal trends were observed in either species. However, a region of significantly enhanced $\mathrm{CH}_{4}$ (up to $20 \mathrm{ppb}$ ) was observed a)

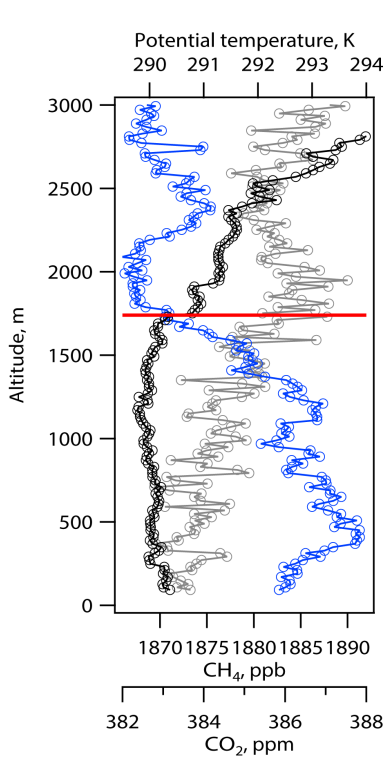

b)
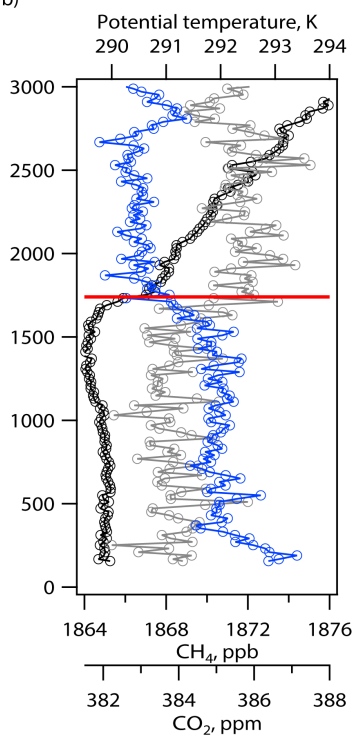

Figure 3. (a) Ascending (01:00 GMT) and (b) descending (15:00 GMT) potential temperature profiles performed over Sodankylä during flight B720, used to determine the boundary layer height as described in the text.

to the north of Sodankylä (Fig. 1), a region with a slightly higher proportion of wetlands ( $29 \%)$.

With a mean PBL mole fraction of $89 \mathrm{ppb}$ for $\mathrm{CO}$ and $26 \mathrm{ppt}$ for $\mathrm{HCN}$, both species remained at mole fractions throughout the flight that are representative of a typical background for the summer at these latitudes (Vay et al., 2011; O'Shea et al., 2013a). This indicates that any biomass burning and anthropogenic emissions within the region were small and well-mixed when sampled by the FAAM BAe- 146 . To identify the source of the observed $\mathrm{CH}_{4}$ enhancements we use the measured $\delta^{13} \mathrm{C}$ isotopic ratios and a Keeling plot methodology (Pataki et al., 2003). Figure 4 shows a Keeling plot for all PBL measurements of $\delta^{13} \mathrm{C}-\mathrm{CH}_{4}$ during the flight on the 22 July 2012 (B720). The vertical intercept represents the isotopic ratio of the source of the enhancements. A source of $-70.2 \pm 3.0 \%$ as seen here is consistent with wetland $\mathrm{CH}_{4}$ emissions ( -71 to $-59 \%$; Fisher et al., 2011; Sriskantharajah et al., 2012).

\subsection{Regional-scale fluxes derived using aircraft observations}

In order to perform a mass budget flux calculation (Eq. 3), we use the fact that the east-west transect performed during the 22 July 2012 flight was aligned nearly parallel with the prevailing wind bearing, which was $258^{\circ}$ during the transects. This gradient $(\Delta S / \Delta x)$ is determined here by first averaging 
Table 1. Land classification key corresponding to Fig. 1c from CORINE land cover 2006. Also included is the proportion of the aircraft's footprint that each classification accounted for during the B720 E-W transects.

\begin{tabular}{|c|c|c|}
\hline Number & Land type & $\begin{array}{r}\text { Proportion of footprint } \\
\text { during E-W transect }(\%)\end{array}$ \\
\hline 2 & Discontinuous urban fabric & 0.1 \\
\hline 3 & Industrial or commercial units & 0.0 \\
\hline 4 & Road and rail networks and associated land & 0.0 \\
\hline 6 & Airports & 0.0 \\
\hline 7 & Mineral extraction sites & 0.0 \\
\hline 8 & Dump sites & 0.0 \\
\hline 10 & Green urban areas & 0.0 \\
\hline 11 & Sport and leisure facilities & 0.0 \\
\hline 12 & Non-irrigated arable land & 0.0 \\
\hline 18 & Pastures & 0.1 \\
\hline 20 & Complex cultivation patterns & 0.0 \\
\hline 21 & $\begin{array}{l}\text { Land principally occupied by agriculture } \\
\text { with significant areas of natural vegetation }\end{array}$ & 0.1 \\
\hline 23 & Broad-leaved forest & 10.4 \\
\hline 24 & Coniferous forest & 24.4 \\
\hline 25 & Mixed forest & 16.3 \\
\hline 26 & Natural grasslands & 0.1 \\
\hline 27 & Moors and heathland & 8.3 \\
\hline 29 & Transitional woodland-shrub & 13.8 \\
\hline 31 & Bare rocks & 0.1 \\
\hline 32 & Sparsely vegetated areas & 2.3 \\
\hline 33 & Burnt areas & 0.0 \\
\hline 34 & Glaciers and perpetual snow & 0.0 \\
\hline 35 & Inland marshes & 0.1 \\
\hline 36 & Peat bogs & 19.6 \\
\hline 40 & Water courses & 0.5 \\
\hline 41 & Water bodies & 3.7 \\
\hline
\end{tabular}

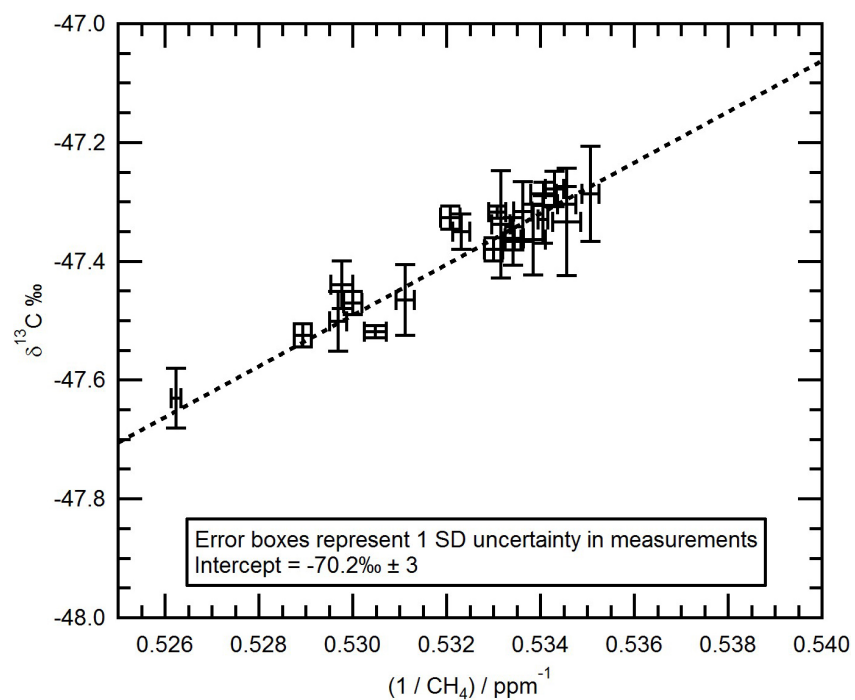

Figure 4. Keeling plot showing PBL measurements of $\delta^{13} \mathrm{C}-$ $\mathrm{CH}_{4}$ during flight on the 22 July 2012 (B720). The intercept of $-70.2 \pm 3.0 \%$ o is representative of a wetland source of $\mathrm{CH}_{4}$. the data to $500 \mathrm{~m}$ intervals (equivalent to around $4 \mathrm{~s}$ of sampling time) along $x$, before performing an orthogonal distance regression (Fig. 2a and b). The regression slope is weighted by the quadrature addition of the analytical uncertainty and the vertical variability of $S$ throughout the PBL (Fig. 3). The $1 \sigma$ of the regression fit is used in the uncertainty propagation to derive a representative and comprehensive uncertainty on the calculated flux.

In situ measurements on board the FAAM BAe-146 are used here to determine the wind direction and speed. The transect, $x$, should ideally be aligned parallel to the wind vector. However, we note that there was a $12^{\circ}$ offset between the mean wind vector and transect $x(\phi$, Eq. 3$)$, while the wind also showed some variation about the mean $\left(24^{\circ}\right.$ at $\left.1 \sigma\right)$. It then has to be assumed that mole fractions perpendicular to the wind vector are constant. The mean wind speed was found to be $6(2$ at $1 \sigma) \mathrm{m} \mathrm{s}^{-1}$ for the longitudinal transects. The $1 \sigma$ of the wind direction and speed is used in the uncertainty propagation.

Based on the observed changing vertical gradient in potential temperature, a PBL height of $1740 \mathrm{~m}$ a.g.l. is determined here from both ascending and descending vertical profiles 
by the FAAM BAe-146, which show strong mixing (constant potential temperature profile) between the ground and the top of the PBL. In addition, above the PBL, both $\mathrm{CO}_{2}$ and $\mathrm{CH}_{4}$ show abrupt changes in their mole fraction and the vertical wind speed becomes less variable (variance in the wind speed above the boundary layer is typically less than $0.2 \mathrm{~m}^{2} \mathrm{~s}^{-2}$ ), supporting the assumption that entrainment into and out of the boundary layer is relatively small and so can be neglected for this exercise.

In order to estimate the uncertainty in the determination of the PBL height we use a simple PBL growth model to estimate the change that could reasonably be expected in the intervening period between the nearest vertical profile and the completion of the longitudinal transect used in the flux calculation (approximately $1 \mathrm{~h}$ ). The change in PBL height, $\Delta z$, over the time period $\Delta t$ can be estimated using Eq. (4) (Stull, 1988; Cambaliza et al., 2014):

$\Delta z=\left(\frac{2 \Delta t \overline{w^{\prime} \theta^{\prime}}}{\gamma}\right)^{1 / 2}$,

where $\gamma$ is the adiabatic lapse rate and $\overline{w^{\prime} \theta^{\prime}}$ is the surface sensible heat flux, which was measured in Sodankylä. Using Eq. (4) changes in the PBL depth are estimated to be of the order of $200 \mathrm{~m}$ within $1 \mathrm{~h}$, which we use as an estimate of the uncertainty in the PBL height during the transects.

Within the boundary layer some structure exists in the altitude profile. The $\mathrm{CH}_{4}$ standard deviation was $4.5 \mathrm{ppb}$ for the ascending profile and $1.7 \mathrm{ppb}$ for the descending profile, while for $\mathrm{CO}_{2}$ this was $1 \mathrm{ppm}$ for both the ascending and descending profiles. Some of this variability is likely to be due to the fact that these profiles are recorded slant-wise in the horizontal and therefore reflect both variability in vertical mixing and the existing horizontal gradient. This variability is included in the error propagation, as mentioned above.

As described in Sect. 3.1, Eq. (3) assumes that emissions are immediately mixed throughout the PBL column. To estimate the PBL turnover time we calculate the Deardoff velocity scale, $w *$, which corresponds to the mean velocity of thermals (Stull, 1988):

$w *=\left(\frac{g Z_{1} \overline{w^{\prime} \theta_{\mathrm{V}}^{\prime}}}{\overline{\theta_{\mathrm{V}}}}\right)^{1 / 3}$,

where $g$ is the acceleration due to gravity, $\overline{w^{\prime} \theta_{\mathrm{V}}^{\prime}}$ is the surface buoyancy flux and $\theta_{\mathrm{V}}$ is the virtual potential temperature. The minimum time period for an air mass to mix from the surface to the top of the PBL is calculated to be $19 \mathrm{~min}$. Complete mixing should occur within approximately three time periods (Karion et al., 2013), in this case $57 \mathrm{~min}$. This is significantly shorter than the time taken for air to advect across the transect (up to $\sim 16 \mathrm{~h}$ ), suggesting that the assumption of instantaneous vertical mixing is reasonable.

The calculated fluxes are found to be $1.2 \pm 0.5 \mathrm{mg} \mathrm{CH}_{4} \mathrm{~h}^{-1} \mathrm{~m}^{-2}$ and $-350 \pm 143 \mathrm{mg} \mathrm{CO}_{2} \mathrm{~h}^{-1}$

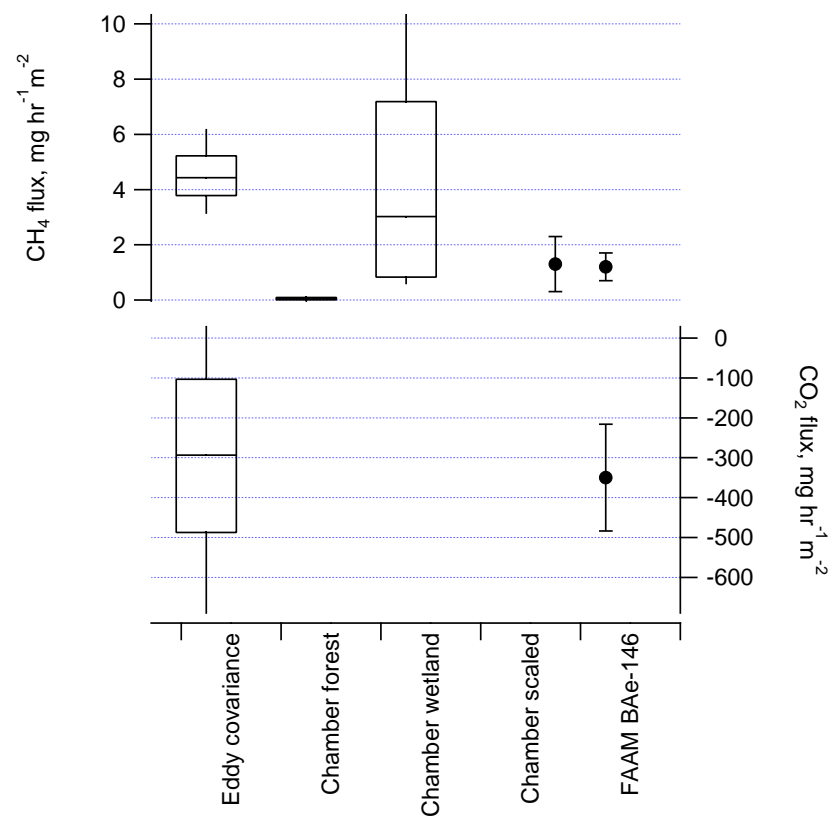

Figure 5. A comparison between different techniques used to determine fluxes. The box extents define the 25th and 75th percentiles, and whiskers are the 10th and 90th percentiles. Note: the eddy covariance percentiles are for daytime (06:00 to 18:00 GMT) only. Forest and wetland chamber fluxes represent summer seasonal statistics for 60 chamber measurements ( 21 in forest regions and 39 in wetland regions). The scaled chamber (black circle) is determined by averaging the wetland and forest chamber fluxes as described in Sect. 4.3. The FAAM BAe-146 and scaled chamber error bar shows the $1 \sigma$ uncertainty as described in Sect. 4.1.

(Table 2 and Fig. 5). The uncertainty in the total flux is determined by propagating the uncertainties associated with the individual terms in Eq. (3); these include the uncertainty in the observed (fitted) spatial mole fraction gradient, known variability in the wind, and boundary layer mixing height, as identified above. Similar to previous studies (e.g. Ryerson et al., 1998), the largest known source of uncertainty was found to be the assumption of a single wind vector for the whole of the transect $x$. Within the uncertainties, the fluxes are in agreement whether separately derived eastward, westward, or combined transects are used in the calculation. The repeatability of this measured gradient further indicates that both species were vertically well mixed since the transects were performed at slightly different altitudes, as shown in Fig. 2c (eastward mean $=507 \mathrm{~m}$, range $=70$ to $1287 \mathrm{~m}$; westward mean $=717 \mathrm{~m}$, range $=103$ to $1382 \mathrm{~m}$ ). The fluxes calculated using the 11 whole-air sample measurements, collected along the east-west transect, are also in excellent agreement (see Table 2) with that from the continuous in situ measurements. However, in the case of $\mathrm{CO}_{2}$ this is with a large uncertainty. 


\subsection{Dispersion modelling}

The flux derived from the aircraft measurements has also been tested using forward model runs with the UK Met Office's Numerical Atmospheric-dispersion Modelling environment (NAME) to diagnose whether the calculated ground flux might be expected to translate into the observed enhancements seen in measurements observed aloft when advected. NAME is a 3-D Lagrangian particle dispersion model (Ryall and Maryon, 1998; Ryall et al., 1998), which is run here using the UK Met Office's Unified Model meteorological fields (Cullen, 1993). A flux of $1.2 \mathrm{mg} \mathrm{CH}_{4} \mathrm{~h}^{-1} \mathrm{~m}^{-2}$ was emitted from the ground in the region bounded by 20 to $28^{\circ} \mathrm{E}$ and 67 to $69.5^{\circ} \mathrm{N}$ continuously for the period from 00:00 GMT on 20 July 2012 to 17:00 GMT on 22 July 2012, and the model was run forwards to disperse the $\mathrm{CH}_{4}$ through the modelled atmosphere. The particle motions are calculated based on the large-scale winds, wind meander and subgrid-scale stochastic turbulence.

Figure 6 shows a cross section of the atmosphere that is coincident with flight B720. The contours show the $1 \mathrm{~h}$ average mixing ratio of $\mathrm{CH}_{4}$ averaged over 67.75 to $68.00^{\circ} \mathrm{N}$ (upper panel for 11:00 GMT and lower panel for 16:00 GMT). This shows the modelled increment of $\mathrm{CH}_{4}$ that comes from the local region, based on the flux calculated by the aircraft observations. At 11:00 GMT (the time of the eastward transect), the increment in $\mathrm{CH}_{4}$ at the eastern end of the flight is approximately 15 to $20 \mathrm{ppb}$ higher than the western part of the transect. By 16:00 GMT, the difference in the model has reduced to $12-15 \mathrm{ppb}$. This is because the model PBL is well mixed, and so gradients within it decline as the day progresses and the PBL top rises. It can be seen in Fig. 6a that the model PBL height is about $2200 \mathrm{~m}$ at 11:00 GMT (corresponding to our eastward transect) and has increased to about $3000 \mathrm{~m}$ by 16:00 GMT (the time of the westward transect). The higher late afternoon modelled PBL would act to dilute the $\mathrm{CH}_{4}$, which can be seen in the lower modelled mixing ratio enhancements at 16:00 GMT (Fig. 6b). However, this dilution was not observed in the late afternoon aircraft measurements, which also showed a much lower PBL height of $1740 \mathrm{~m}$ (Fig. 3), similar to that observed earlier in the day.

Despite this, the increment to $\mathrm{CH}_{4}$ is comparable for the 11:00 case (approximately $20 \mathrm{ppb}$ in the observations, and approximately $15-20 \mathrm{ppb}$ in the dispersion model). The reason for the difference in PBL height between the model and measurement cannot currently be explained and is beyond the scope of this study; however, these results confirm that observed enhancements can be reasonably represented by dispersion modelling when treating the land as a constant source equal to that derived here, for a PBL mixing height of $\sim 2200 \mathrm{~m}$ (as modelled for the 11:00 GMT transect). a)

1h-average $\mathrm{CH}_{4}$ increment (ppbv) averaged over $67.75-68.00 \mathrm{~N}$ at $11 \mathrm{Z}$ on 22 July 2012

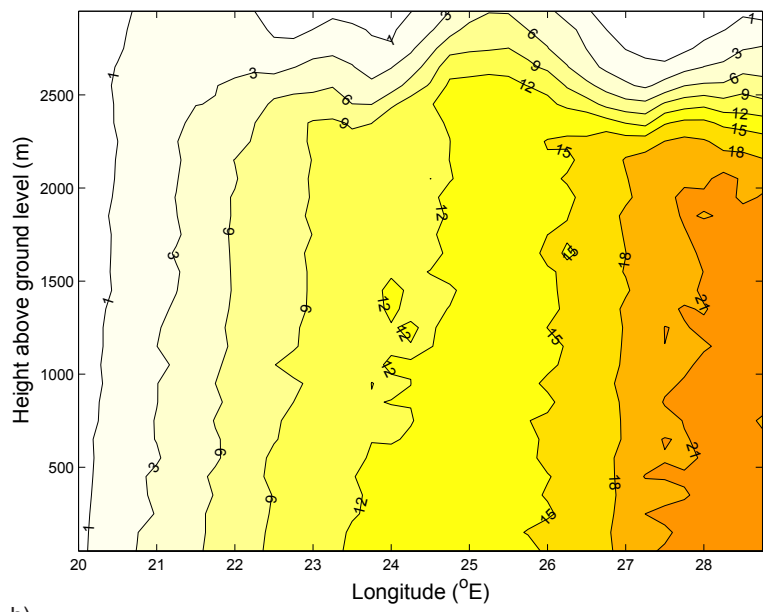

b)

1h-average $\mathrm{CH}_{4}$ increment (ppbv) averaged over 67.75-68.00N at $16 \mathrm{Z}$ on 22 July 2012

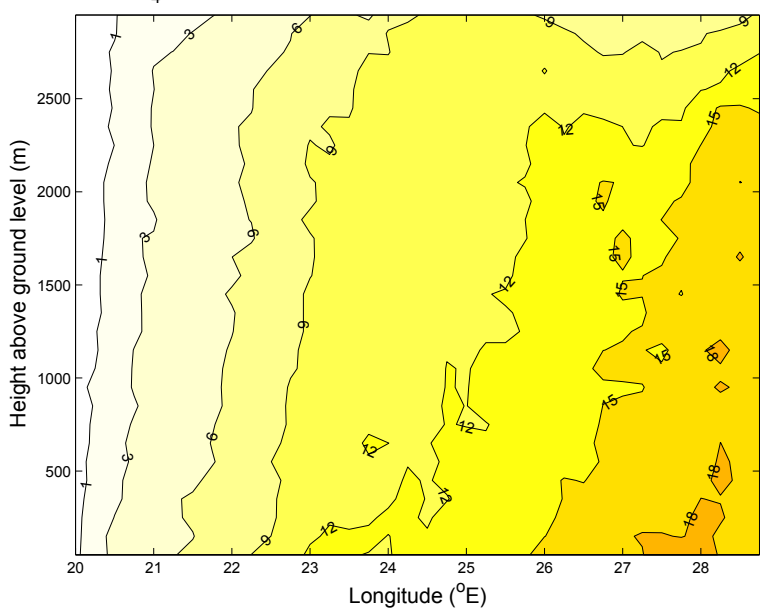

Figure 6. Dispersion model results from NAME for the mixing ratio of $\mathrm{CH}_{4}$ originating from the local wetlands in a cross section of the atmosphere averaged over 67.75 to $68.00^{\circ} \mathrm{N}$ and $1 \mathrm{~h}$ surrounding 11:00 GMT on 22 July 2012. The local wetland $\mathrm{CH}_{4}$ source was defined as a $1.2 \mathrm{mg} \mathrm{CH}_{4} \mathrm{~h}^{-1} \mathrm{~m}^{-2}$ source emitted from the ground between 20 and $28^{\circ} \mathrm{E}$ and between 67 and $69.5^{\circ} \mathrm{N}$. Figure $6 \mathrm{~b}$ shows the same but for a $1 \mathrm{~h}$ average surrounding 16:00 GMT on the same day.

\subsection{Ground-based flux measurements}

In this section, we compare the aircraft-derived flux with seasonally averaged surface measurements to examine scalability and potential sources of bias (e.g. spatial heterogeneity). The ground-based measurements during the MAMM campaign comprised both chamber and eddy covariance flux measurements, as described in Sect. 2.2. A comparison between these two techniques and the aircraft-determined flux is complicated by the differences in their respective footprints. Chambers are the smallest scale $(<1 \mathrm{~m})$ and are specific to a single land type. While eddy covariance fluxes are typically representative of 100 to $1000 \mathrm{~m}$ and as a result may 
Table 2. Mean fluxes determined using the FAAM BAe-146, chamber and eddy covariance techniques. All uncertainties given are as one standard deviation $(1 \sigma)$. Chamber measurements are separated into the geometric mean of all seasonally averaged measurements and only those from the 22 July 2012. A weighted mean of the wetland and forest chamber fluxes is calculated using the number of occurrences of each land type within the east-west transect (Fig. 1b).

\begin{tabular}{llrr}
\hline & & \multicolumn{2}{c}{ Flux $\left(\mathrm{mg} \mathrm{h}^{-1} \mathrm{~m}^{-2}\right)$} \\
\cline { 3 - 4 } & & $\mathrm{CH}_{4}$ & $\mathrm{CO}_{2}$ \\
\hline \multirow{4}{*}{ FAAM BAe-146 } & Eastward transect & $1.1 \pm 0.6$ & $-375 \pm 202$ \\
& Westward transect & $1.6 \pm 0.5$ & $-357 \pm 135$ \\
& Both transects & $1.2 \pm 0.5$ & $-350 \pm 143$ \\
& Whole-air samples & $1.0 \pm 0.6$ & $-315 \pm 368$ \\
\hline \multirow{5}{*}{ Eddy covariance } & $4.5 \pm 1.4$ & $-135 \pm 344$ \\
& Summer & $4.5 \pm 1.2$ & $-309 \pm 306$ \\
& Summer day & $4.4 \pm 1.6$ & $71 \pm 264$ \\
& Summer night & $4.5 \pm 0.9$ & \\
& 22 July 2012 & $4.9 \pm 0.6$ & \\
& 22 July 2012 day & $4.4 \pm 1.0$ & \\
& 22 July 2012 night & $4.5 \pm 3.7$ & \\
\hline \multirow{5}{*}{ Chamber } & Wetland summer & $5.6 \pm 5.6$ & \\
& Wetland 22 July 2012 & $0.05 \pm 0.07$ & \\
& Forest summer & $-0.07 \pm 0.05$ & \\
& Forest 22 July 2012 & $1.3 \pm 1.0$ & \\
& Weighted average & $1.5 \pm 1.6$ & \\
& Weighted average 22 July 2012 &
\end{tabular}

average the flux across several land types. The aircraft represents a regional flux, in this case $>300 \mathrm{~km}$, which encompasses several ecosystems with air mixed over all.

During the MAMM field campaign, 60 chambers were used to determine $\mathrm{CH}_{4}$ fluxes. Fluxes for the entire measurement period, as well as those for just 22 July 2012, are given in Table 2 and Fig. 5. Forested regions are found to have negligible net flux, varying between a small source or sink (Ridgwell et al., 1999), while the wetlands show a wide range of net emissions, which could be expected since the chambers covered a wide range of soil moisture saturations.

The aircraft-derived $\mathrm{CH}_{4}$ flux is within the wide range spanned by the forest and wetland chamber measurements ( -0.09 to $11.6 \mathrm{mg} \mathrm{CH}_{4} \mathrm{~h}^{-1} \mathrm{~m}^{-2}$ ). This might be expected as both ecosystems are present within the aircraft's footprint (Fig. 1). For a more direct comparison we perform a weighted average of the two classes of chamber fluxes. This was done by first determining the aircraft's surface footprint using the NAME model. The CORINE land cover map was then used to identify the prevalence of the each land classification within this footprint (Table 1). Each CORINE classification was grouped as either a forest (coniferous forest, mixed forest, transitional woodland, broad-leaved forest) or a wetland (peat bog, moor and heathland) land type. Using this methodology, during the 22 July flight's east-west transect, $28 \%$ of the land footprint was classified as wetland and $65 \%$ was classified as forest. These proportions were then used to weight the averaging of the two chamber flux categories. The result of this is $1.3 \pm 1.0 \mathrm{mg} \mathrm{CH}_{4} \mathrm{~h}^{-1} \mathrm{~m}^{-2}$ (mean \pm standard deviation) using the summer mean chambers and $1.5 \pm 1.6 \mathrm{mg} \mathrm{CH}_{4} \mathrm{~h}^{-1} \mathrm{~m}^{-2}$ if just the 22 July 2012 measurements are used. Though poorly constrained, these are both in good agreement with the aircraft-derived flux, which is only $0.1 \mathrm{mgCH}_{4} \mathrm{~h}^{-1} \mathrm{~m}^{-2}$ and $0.3 \mathrm{mg} \mathrm{CH}_{4} \mathrm{~h}^{-1} \mathrm{~m}^{-2}$ lower, respectively (Fig. 5). Uncertainties exist in this comparison since the partitioning is quite broad and in the assumption of a zero flux for $7 \%$ of the land area. A more sophisticated comparison would assign measured fluxes for each 2006 CORINE land cover. Nevertheless this simple approach provides a useful validation of the airborne calculation.

The $\mathrm{CH}_{4}$ and $\mathrm{CO}_{2}$ eddy covariance flux measurements were calculated for the Sodankylä wetland from 1 July 2012 to 15 August 2012 (Table 2 and Figs. 7-8). $\mathrm{CH}_{4}$ chamber fluxes show a wider range than the eddy covariance fluxes, which could be expected since they covered the dryer and wetter parts of the wetland, while the eddy covariance method spatially integrates these regions and as a consequence is within this range. $\mathrm{CH}_{4}$ fluxes do not show large variation over diurnal (Fig. 7) or weekly timescales (Fig. 8). However, $\mathrm{CO}_{2}$ was emitted for several hours around midnight, while uptake occurred during the day. The mean daytime (06:00 to 18:00 GMT) eddy covariance $\mathrm{CO}_{2}$ measurement of $-309(1 \sigma=306) \mathrm{mg} \mathrm{CO}_{2} \mathrm{~h}^{-1} \mathrm{~m}^{-2}$ is only $41 \mathrm{mg} \mathrm{CO}_{2} \mathrm{~h}^{-1} \mathrm{~m}^{-2}$ higher than the aircraft-derived flux, well within the measurement uncertainty.

However, the mean daytime eddy covariance $\mathrm{CH}_{4}$ flux of $4.5 \pm 1.2 \mathrm{mg} \mathrm{CH}_{4} \mathrm{~h}^{-1} \mathrm{~m}^{-2}$ for the summer 


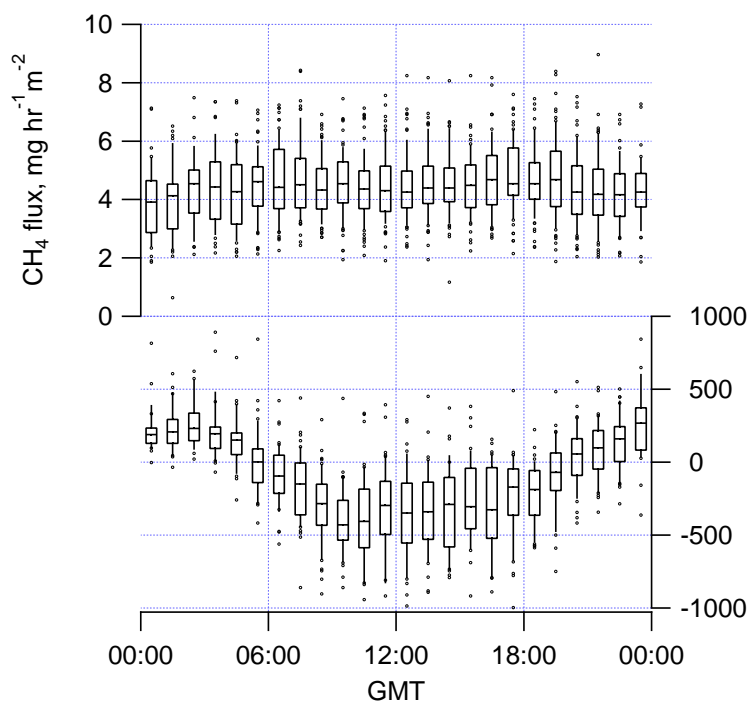

Figure 7. $\mathrm{CH}_{4}$ and $\mathrm{CO}_{2}$ hourly fluxes at Sodankylä wetland site between 1 July and 15 August 2012 determined using the eddy covariance technique. $\mathrm{CH}_{4}$ diurnal variation is noted to be small. Net $\mathrm{CO}_{2}$ uptake occurs during the day, with net emission during the night.

period is a factor of 4 larger than the aircraft. This is comparable with some other previous studies in wetlands such as $4.7 \mathrm{mg} \mathrm{CH}_{4} \mathrm{~m}^{-2} \mathrm{~h}^{-1}$ (2004 to 2006) and $6.2 \pm 2.6 \mathrm{mg} \mathrm{CH}_{4} \mathrm{~m}^{-2} \mathrm{~h}^{-1}$ (2006 and 2007) for Stordalen (Petrescu et al., 2008; Jackowicz-Korczynski et al., 2010). Similar to the chamber measurements, this may be because the eddy covariance footprint is more specific to a single land type than the aircraft in this instance. To test this, the same scaling was repeated using the CORINE land cover classification but this time using the Sodankylä wetland eddy covariance flux instead of that from the wetland chambers, which resulted in a flux of $1.3 \pm 0.3 \mathrm{mg}$ $\mathrm{CH}_{4} \mathrm{~h}^{-1} \mathrm{~m}^{-2}$. This then displays similarly good agreement with the aircraft-derived flux.

\subsection{Comparison against modelled wetland emission estimates}

In this section, we compare our measurement-derived $\mathrm{CH}_{4}$ emission fluxes with those predicted from wetlands in Fennoscandia by two land surface models: JULES and HYBRID8. The purpose of this comparison is to investigate how representative the regional snapshot we discuss above is, in the context of predicted seasonal and interannual variability, and to discuss potential sources of systematic bias.

For this comparison, runs of the JULES and HYBRID8 models were done on a $0.5^{\circ} \times 0.5^{\circ}$ terrestrial grid covering Scandinavia, using the CRU-NCEP (Climatic Research UnitNational Centers for Environmental Prediction) meteorological data set (Viovy and Ciais, 2009). Hourly $\mathrm{CH}_{4}$ emission fluxes from wetlands were derived between January 1980 and

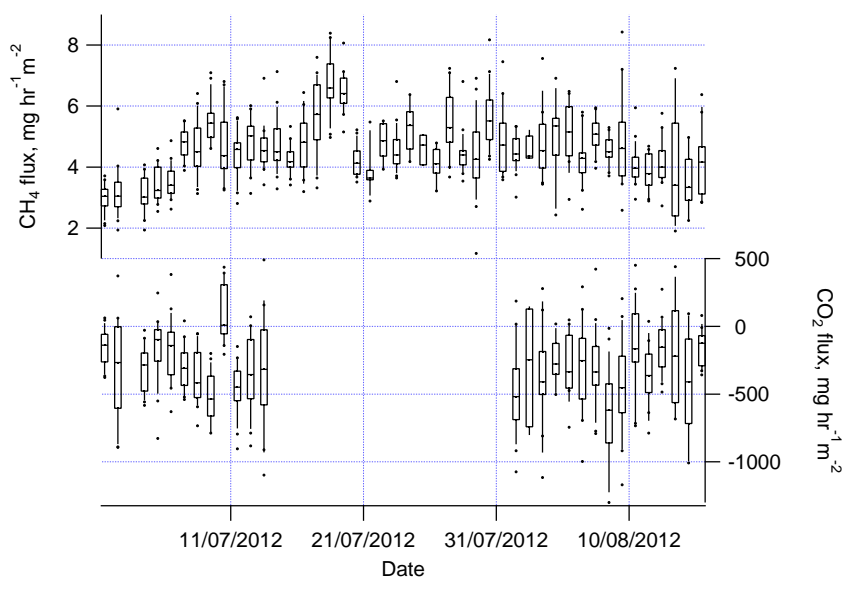

Figure 8. Daytime (06:00-18:00) $\mathrm{CH}_{4}$ and $\mathrm{CO}_{2}$ fluxes at Sodankylä wetland site between 1 July and 15 August 2012 determined using the eddy covariance technique. Note: $\mathrm{CO}_{2}$ fluxes are not shown for the period 14 July 2012 to 1 August 2012 as it was not possible to calibrate the LI-7200's $\mathrm{CO}_{2}$ channel in that period.

December 2012 (the last year currently available in the CRUNCEP driving meteorological data set). Table 3 summarises the statistics derived from the modelled hourly $\mathrm{CH}_{4}$ emission for the domain covered by the aircraft $\left(20.0-29.0^{\circ} \mathrm{E}, 67.5-\right.$ $68.5^{\circ} \mathrm{N}$ ) for July-August 2012 and for all the July-August's between 1980 and 2012. The modelled fluxes for 2012 are slightly higher but consistent with those derived from every July and August in the 33-year model run (also shown in Table 3).

It is evident that the two models significantly underestimate (a factor $\sim 14$ for JULES and Hybrid in the mean) the $\mathrm{CH}_{4}$ emission flux in this region for July-August 2012, when compared to our regionally representative case study. Furthermore, even the upper quartile maximum monthly averaged flux in the 31-year climatology $\left(0.11 \mathrm{mg} \mathrm{CH}_{4} \mathrm{~h}^{-1} \mathrm{~m}^{-2}\right.$ for JULES and $0.13 \mathrm{mg} \mathrm{CH}_{4} \mathrm{~h}^{-1} \mathrm{~m}^{-2}$ for HYBRID8) does not approach the measured aircraft and ground-based results in this case study. This is possibly because of an under-prediction of wetland extent by both models in this region, which could be linked to the topographical data set used and/or the absence of an organic soil type related to peatlands. Such soils would have very different hydraulic properties to the mineral soil types currently used in JULES and HYBRID8. Water would be retained at or close to the surface increasing the area of wetlands. Model emission fluxes were derived assuming that each grid cell is all wetland. These results were found to be much closer to the aircraft values for both JULES (JulyAugust 2012: median $1.6 \mathrm{mg} \mathrm{CH}_{4} \mathrm{~h}^{-1} \mathrm{~m}^{-2}$, inter-quartile range 1.4 to $1.8 \mathrm{mg} \mathrm{CH}_{4} \mathrm{~h}^{-1} \mathrm{~m}^{-2}$ ) and HYBRID8 (2012: median $1.9 \mathrm{mg} \mathrm{CH}_{4} \mathrm{~h}^{-1} \mathrm{~m}^{-2}$, inter-quartile range 1.6 to $2.6 \mathrm{mg} \mathrm{CH}_{4} \mathrm{~h}^{-1} \mathrm{~m}^{-2}$ ). This suggests that underestimation of the area of wetlands in both models is probably the ma- 
Table 3. Distribution of the modelled hourly wetland methane emission fluxes $\left(\mathrm{mg} \mathrm{CH}_{4} \mathrm{~m}^{-2} \mathrm{~h}^{-1}\right)$ for the domain $\left(20.0-29.0^{\circ} \mathrm{E}\right.$, 67.5$68.5^{\circ} \mathrm{N}$ ) for two periods: July-August 2012 and the July-August climatology between 1980 and 2012.

\begin{tabular}{|c|c|c|c|c|}
\hline \multirow{2}{*}{$\begin{array}{l}\text { Hourly emission flux } \\
\left(\mathrm{mg} \mathrm{CH}_{4} \mathrm{~m}^{-2} \mathrm{~h}^{-1}\right)\end{array}$} & \multicolumn{2}{|c|}{ JULES } & \multicolumn{2}{|c|}{ HYBRID8 } \\
\hline & $\begin{array}{r}\text { July-August } \\
2012\end{array}$ & $\begin{array}{r}\text { July-August } \\
1980-2012\end{array}$ & $\begin{array}{r}\text { July-August } \\
2012\end{array}$ & $\begin{array}{r}\text { July-August } \\
1980-2012\end{array}$ \\
\hline Number of non-zero fluxes & 53568 & 1767744 & 53568 & 1767744 \\
\hline Total number & 53568 & 1767744 & 53568 & 1767744 \\
\hline Minimum & 0.0 & 0.0 & 0.008 & -0.002 \\
\hline Lower quartile & 0.057 & 0.018 & 0.016 & 0.013 \\
\hline Median & 0.082 & 0.063 & 0.023 & 0.024 \\
\hline Upper quartile & 0.11 & 0.11 & 0.126 & 0.097 \\
\hline Maximum & 0.21 & 0.41 & 1.53 & 4.62 \\
\hline Mean & 0.084 & 0.073 & 0.088 & 0.074 \\
\hline
\end{tabular}

jor reason for the under-prediction of the wetland emission fluxes in this region. Petrescu et al. (2010) investigated the sensitivity to the wetland area and found a wide variation in methane emission fluxes ( 37.7 to $157.3 \mathrm{Tg} \mathrm{CH}_{4} \mathrm{yr}^{-1}$ ) from wetlands and floodplains above $30^{\circ} \mathrm{N}$ for the years 2001 to 2006 for different estimates of wetland extent. The wetland model intercomparison (Melton et al., 2013) has further highlighted the major challenges and uncertainties that exist in modelling wetlands and the associated $\mathrm{CH}_{4}$ emissions.

Both the JULES and HYBRID8 models have been used to simulate the response of past and future emissions to climate change (Gedney et al., 2004; Friend, 2010; Quiquet et al., 2014). The results from this comparison suggest that there are significant uncertainties when emissions are simulated at regional scales and/or at specific times. Although our snapshot of a regionally representative flux on a single day should not be directly extrapolated to demonstrate a systematic under-bias in the climatological Arctic wetland $\mathrm{CH}_{4}$ flux as predicted by JULES and HYBRID8, these results do point to the important need for further such case studies from which to build diagnostic statistics to validate such models. Given that this study suggests an order of magnitude underbias in modelled fluxes, this uncertainty is potentially very important for climate studies that model $\mathrm{CH}_{4}$ emissions scenarios.

\section{Conclusions}

As part of the MAMM field project, airborne measurements of $\mathrm{CH}_{4}$ and $\mathrm{CO}_{2}$ were collected in the European Arctic in summer 2012. An airborne mass balance approach was used to derive regional-scale fluxes for the northern Scandinavian wetlands from one flight on the 22 July 2012. These were established to be $1.2 \pm 0.5 \mathrm{mg} \mathrm{CH}_{4} \mathrm{~h}^{-1} \mathrm{~m}^{-2}$ and $-350 \pm 143 \mathrm{mg} \mathrm{CO}_{2} \mathrm{~h}^{-1} \mathrm{~m}^{-2}$, which were comparable with simultaneous seasonally averaged chamber and eddy covariance flux measurements made in Sodankylä (within $11 \%$ for
$\mathrm{CO}_{2}$ and $8 \%$ for $\mathrm{CH}_{4}$ if the fluxes were scaled using the land type). The internal consistency of the aircraft-derived fluxes across a wide swath of Fennoscandia coupled with an excellent statistical comparison with local seasonally averaged ground-based measurements demonstrates the potential scalability of such localised measurements to regional-scale representativeness.

Though the fluxes calculated here do not provide information about the wider temporal variability of fluxes, they do provide a snapshot that can be compared with the statistical climatology for model fluxes in the region, which is representative of a spatial scale that is comparable with the resolution of regional chemical transport and land surface models. This together with a well-characterised uncertainty mean that these fluxes can provide a useful constraint for "bottomup" regional flux calculations. To this end, a comparison with both the HYBRID8 and JULES land surface model suggests that they both significantly underestimate the net $\mathrm{CH}_{4}$ flux from these regions (a factor $\sim 14$ for JULES and HYBRID8 in the mean).

Although our snapshot of a regionally representative flux on a single day should not be directly extrapolated to demonstrate a systematic under-bias in the modelled climatological Arctic wetland methane flux, the results presented here do point to the important need for further such case studies from which to build diagnostic statistics to validate such models, as this uncertainty is potentially very important for climate studies that model $\mathrm{CH}_{4}$ emissions scenarios. Future field campaigns and studies are planned to exploit the MAMM airborne data set from the 2013 and 2014 flights, to derive additional regional-scale fluxes of key greenhouse gases either through mass balance approaches, as illustrated here, or inverse modelling. These may provide additional information on the consistency of the disagreement between observations and the JULES/HYBRID8 models at high northern latitudes. 
Acknowledgements. The MAMM project was funded by the UK Natural Environment Research Council (grant NE/I029293/1). S. J. O'Shea is in receipt of a NERC studentship and G. Allen is a NERC Fellow (no. NE/I021276/1). Airborne data were obtained using the FAAM BAe-146 Atmospheric Research Aircraft (ARA) operated by Directflight Ltd (DFL) and managed by the Facility for Airborne Atmospheric Measurements (FAAM), which is a joint entity of the Natural Environment Research Council (NERC) and the UK Meteorological Office. The CORINE land cover map was obtained from http://www.eea.europa.eu/data-and-maps/ data/corine-land-cover-2006-raster, the copyright holder is the European Environment Agency (EEA). A. Friend and A. Quiquet received funding from the European Community's Seventh Framework Programme (FP7 2007-2013) under grant agreement no. 238366.

Edited by: J. Rinne

\section{References}

Allen, G., Coe, H., Clarke, A., Bretherton, C., Wood, R., Abel, S. J., Barrett, P., Brown, P., George, R., Freitag, S., McNaughton, C., Howell, S., Shank, L., Kapustin, V., Brekhovskikh, V., Kleinman, L., Lee, Y.-N., Springston, S., Toniazzo, T., Krejci, R., Fochesatto, J., Shaw, G., Krecl, P., Brooks, B., McMeeking, G., Bower, K. N., Williams, P. I., Crosier, J., Crawford, I., Connolly, P., Allan, J. D., Covert, D., Bandy, A. R., Russell, L. M., Trembath, J., Bart, M., McQuaid, J. B., Wang, J., and Chand, D.: South East Pacific atmospheric composition and variability sampled along $20^{\circ} \mathrm{S}$ during VOCALS-REx, Atmos. Chem. Phys., 11, 5237-5262, doi:10.5194/acp-11-5237-2011, 2011.

Allen, G., Illingworth, S. M., O'Shea, S. J., Newman, S., Vance, A., Bauguitte, S. J.-B., Marenco, F., Kent, J., Bower, K., Gallagher, M. W., Muller, J., Percival, C. J., Harlow, C., Lee, J., and Taylor, J. P.: Atmospheric composition and thermodynamic retrievals from the ARIES airborne TIR-FTS system - Part 2: Validation and results from aircraft campaigns, Atmos. Meas. Tech. Discuss., 7, 3397-3441, doi:10.5194/amtd-7-3397-2014, 2014.

Anthony, K. M. W., Anthony, P., Grosse, G., and Chanton, J.: Geologic methane seeps along boundaries of Arctic permafrost thaw and melting glaciers, Nat. Geosci., 5, 419-426, doi:10.1038/ngeo1480, 2012

Aubinet, M., Grelle, A., Ibrom, A., Rannik, U., Moncrieff, J., Foken, T., Kowalski, A. S., Martin, P. H., Berbigier, P., Bernhofer, C., Clement, R., Elbers, J., Granier, A., Grunwald, T., Morgenstern, K., Pilegaard, K., Rebmann, C., Snijders, W., Valentini, R., and Vesala, T.: Estimates of the annual net carbon and water exchange of forests: The EUROFLUX methodology, Adv. Ecol. Res., 30, 113-175, 2000.

Aurela, M., Lohila, A., Tuovinen, J.-P., Hatakka, J., Riutta, T., and Laurila, T.: Carbon dioxide exchange on a northern boreal fen, Boreal Environ. Res., 14, 699-710, 2009.

Best, M. J., Pryor, M., Clark, D. B., Rooney, G. G., Essery, R .L. H., Ménard, C. B., Edwards, J. M., Hendry, M. A., Porson, A., Gedney, N., Mercado, L. M., Sitch, S., Blyth, E., Boucher, O., Cox, P. M., Grimmond, C. S. B., and Harding, R. J.: The Joint UK Land Environment Simulator (JULES), model description -
Part 1: Energy and water fluxes, Geosci. Model Dev., 4, 677-699, doi:10.5194/gmd-4-677-2011, 2011.

Beven, K. J. and Kirkby, M. J.: A physically based, variable contributing area model of basin hydrology, Hydrol. Sci. Bull., 24, 43-69, 1979.

Bousquet, P., Ringeval, B., Pison, I., Dlugokencky, E. J., Brunke, E.G., Carouge, C., Chevallier, F., Fortems-Cheiney, A., Frankenberg, C., Hauglustaine, D. A., Krummel, P. B., Langenfelds, R. L., Ramonet, M., Schmidt, M., Steele, L. P., Szopa, S., Yver, C., Viovy, N., and Ciais, P.: Source attribution of the changes in atmospheric methane for 2006-2008, Atmos. Chem. Phys., 11, 3689-3700, doi:10.5194/acp-11-3689-2011, 2011.

Bridgham, S. D., Cadillo-Quiroz, H., Keller, J. K., and Zhuang, Q.: Methane emissions from wetlands: biogeochemical, microbial, and modeling perspectives from local to global scales, Glob. Change Biol., 19, 1325-1346, 2013.

Cambaliza, M. O. L., Shepson, P. B., Caulton, D. R., Stirm, B., Samarov, D., Gurney, K. R., Turnbull, J., Davis, K. J., Possolo, A., Karion, A., Sweeney, C., Moser, B., Hendricks, A., Lauvaux, T., Mays, K., Whetstone, J., Huang, J., Razlivanov, I., Miles, N. L., and Richardson, S. J.: Assessment of uncertainties of an aircraft-based mass balance approach for quantifying urban greenhouse gas emissions, Atmos. Chem. Phys., 14, 9029-9050, doi:10.5194/acp-14-9029-2014, 2014.

Choularton, T. W., Gallagher, M. W., Bower, K. N., Fowler, D., Zahniser, M., and Kaye, A.: Trace gas flux measurements at the landscape scale using boundary-layer budgets, Philos. T. R. Soc. A, 351, 357-368, doi:10.1098/rsta.1995.0039, 1995.

Christensen, T. R., Johansson, T., Olsrud, M., Strom, L., Lindroth, A., Mastepanov, M., Malmer, N., Friborg, T., Crill, P., and Callaghan, T. V.: A catchment-scale carbon and greenhouse gas budget of a subarctic landscape, Philos. T. R. Soc. A, 365, 16431656, doi:10.1098/rsta.2007.2035, 2007.

Christensen, T. R., Jackowicz-Korczynski, M., Aurela, M., Crill, P., Heliasz, M., Mastepanov, M., and Friborg, T.: Monitoring the Multi-Year Carbon Balance of a Subarctic Palsa Mire with Micrometeorological Techniques, Ambio, 41, 207-217, doi:10.1007/s13280-012-0302-5, 2012.

Clark, D. B., Mercado, L. M., Sitch, S., Jones, C. D., Gedney, N., Best, M. J., Pryor, M., Rooney, G. G., Essery, R. L. H., Blyth, E., Boucher, O., Harding, R. J., Huntingford, C., and Cox, P. M.: The Joint UK Land Environment Simulator (JULES), model description - Part 2: Carbon fluxes and vegetation dynamics, Geosci Model Dev., 4, 701-722, doi:10.5194/gmd-4-701-2011, 2011.

Cullen, M. J. P.: The Unified Forecast/Climate Model, Meteorol. Mag., 1449, 81-94, 1993.

Davidson, E. A. and Janssens, I. A.: Temperature sensitivity of soil carbon decomposition and feedbacks to climate change, Nature, 440, 165-173, doi:10.1038/nature04514, 2006.

Desjardins, R. L., MacPherson, J. I., Mahrt, L., Schuepp, P., Pattey, E., Neumann, H., Baldocchi, D., Wofsy, S., Fitzjarrald, D., McCaughey, H., and Joiner, D. W.: Scaling up flux measurements for the boreal forest using aircraft-tower combinations, J. Geophys. Res., 102, 29125-29133, 1997.

Draxler, R. R. and Rolph, G. D.: HYSPLIT (Hybrid Single-Particle Lagrangian Integrated Trajectory) Model, NOAA Air Resources Laboratory, Silver Spring, MD, USA, 2003.

Fisher, R., Lowry, D., Wilkin, O., Sriskantharajah, S., and Nisbet, E. G.: High-precision, automated stable isotope analysis of at- 
mospheric methane and carbon dioxide using continuous-flow isotope-ratio mass spectrometry, Rapid Commun. Mass Spectrom., 20, 200-208, doi:10.1002/rcm.2300, 2006.

Fisher, R. E., Sriskantharajah, S., Lowry, D., Lanoisellé, M., Fowler, C. M. R., James, R. H., Hermansen, O., Lund Myhre, C., Stohl, A., Greinert, C., Nisbet-Jones, P. B. R., Mienert, J., and Nisbet, E. G.: Arctic methane sources: Isotopic evidence for atmospheric inputs, Geophys. Res. Lett., 38, L21803, doi:10.1029/2011GL049319, 2011.

Forster, P. and Ramaswamy, V.: Changes in Atmospheric Constituents and in Radiative Forcing, Climate Change 2007: the Physical Science Basis, 129-234, Cambridge University Press, Cambridge, 2007.

Friend, A. D.: Terrestrial plant production and climate change, J. Exp. Bot., 61, 1293-1309, 2010.

Friend, A. D. and Kiang, N. Y.: Land surface model development for the GISS GCM: Effects of improved canopy physiology on simulated climate, J. Climate, 18, 2883-2902, doi:10.1175/JCLI3425.1, 2005.

Gallagher, M. W., Choularton, T. W., Bower, K. N., Stromberg, I. M., Beswick, K. M., Fowler, D., and Hargreaves, K. J.: Measurments of methane fluxes on the landscape scale from a wetland area in north Scotland, Atmos. Environ., 28, 2421-2430, doi:10.1016/1352-2310(94)90394-8, 1994.

Gedney, N. and Cox, P. M.: The sensitivity of global climate model simulations to the representation of soil moisture heterogeneity, J. Hydrometeorol., 4, 1265-1275, 2003.

Gedney, N., Cox, P. M., and Huntingford C.: Climate feedback from wetland methane emissions, Geophys. Res. Lett., 31, L20503, doi:10.1029/2004GL020919, 2004.

Gerbig, C., Schmitgen, S., Kley, D., Volz-Thomas, A., Dewey, K., and Haaks, D.: An improved fast-response vacuum-UV resonance fluorescence CO instrument, J. Geophys. Res.-Atmos., 104, 1699-1704, doi:10.1029/1998jd100031, 1999.

Hiller, R. V., Neininger, B., Brunner, D., Gerbig, C., Bretscher, D., Künzle, T., Buchmann, N., and Eugster, W.: Aircraft-based $\mathrm{CH}_{4}$ flux estimates for validation of emissions from an agriculturally dominated area in Switzerland, J. Geophys. Res.-Atmos., 119, 4874-4887, doi:10.1002/2013JD020918, 2014.

Isaksen, I. S. A., Gauss, M., Myhre, G., Anthony, K. M. W., and Ruppel, C.: Strong atmospheric chemistry feedback to climate warming from Arctic methane emissions, Global Biogeochem. Cy., 25, GB2002, doi:10.1029/2010gb003845, 2011.

Jackowicz-Korczynski, M., Christensen, T. R., Backstrand, K., Crill, P., Friborg, T., Mastepanov, M., and Strom, L.: Annual cycle of methane emission from a subarctic peatland, J. Geophys. Res.-Biogeo., 115, G02009, doi:10.1029/2008jg000913, 2010.

Karion, A., Sweeney, C., Petron, G., Frost, G., Hardesty, R. M., Kofler, J., Miller, B. R., Newberger, T., Wolter, S., Banta, R., Brewer, A., Dlugokencky, E., Lang, P., Montzka, S. A., Schnell R., Tans, P., Trainer, M., Zamora, R., and Conley, S.: Methane emissions estimate from airborne measurements over a western United States natural gas field, Geophys. Res. Lett., 40, 1-5, doi:10.1002/grl.50811, 2013.

Kirschke, S., Bousquet, P., Ciais, P., Saunois, M., Canadell, J. G., Dlugokencky, E. J., Bergamaschi, P., Bergmann, D., Blake, D. R., Bruhwiler, L., Cameron-Smith, P., Castaldi, S., Chevallier, F., Feng, L., Fraser, A., Heimann, M., Hodson, E. L., Houweling, S., Josse, B., Fraser, P. J., Krummel, P. B., Lamarque, J.-
F., Langenfelds, R. L., Le Quere, C., Naik, V., O’Doherty, S., Palmer, P. I., Pison, I., Plummer, D., Poulter, B., Prinn, R. G., Rigby, M., Ringeval, B., Santini, M., Schmidt, M., Shindell, D. T., Simpson, I. J., Spahni, R., Steele, L. P., Strode, S. A., Sudo, K., Szopa, S., van der Werf, G. R., Voulgarakis, A., van Weele, M., Weiss, R. F., Williams, J. E., and Zeng, G.: Three decades of global methane sources and sinks, Nat. Geosci., 6, 813-823, doi:10.1038/ngeo1955, 2013.

Kort, E. A., Wofsy, S. C., Daube, B. C., Diao, M., Elkins, J. W., Gao, R. S., Hintsa, E. J., Hurst, D. F., Jimenez, R., Moore, F. L., Spackman, J. R., and Zondlo, M. A.: Atmospheric observations of Arctic Ocean methane emissions up to $82^{\circ}$ north, Nat. Geosci., 5, 318-321, doi:10.1038/ngeo1452, 2012.

Le Breton, M., Bacak, A., Muller, J. B. A., O’Shea, S. J., Xiao, P., Ashfold, M. N. R., Cooke, M. C., Batt, R., Shallcross, D. E., Oram, D. E., Forster, G., Bauguitte, S. J.-B., Palmer, P. I., Parrington, M., Lewis, A. C., Lee, J. D., and Percival, C. J.: Airborne hydrogen cyanide measurements using a chemical ionisation mass spectrometer for the plume identification of biomass burning forest fires, Atmos. Chem. Phys., 13, 92179232, doi:10.5194/acp-13-9217-2013, 2013.

Levy P. E., Gray, A., Leeson, S. R., Gaiawyn, J., Kelly, M. P. C., Cooper, M. D. A., Dinsmore, K. J., Jones, S. K., and Sheppard, L. J.: Quantification of uncertainty in trace gas fluxes measured by the static chamber method, Eur. J. Soil Sci., 62, 811-821, 2011.

Levy, P. E., Burden, A., Cooper, M. D. A., Dinsmore, K. J., Drewer, J., Evans, C., Fowler, D., Gaiawyn, J., Gray, A., Jones, S. K., Jones, T., McNamara, N. P., Mills, R., Ostle, N., Sheppard, L. J., Skiba, U., Sowerby, A., Ward, S. E., and Zielinski, P.: Methane emissions from soils: synthesis and analysis of a large UK data set, Glob. Change Biol., 18, 1657-1669, doi:10.1111/j.13652486.2011.02616.x, 2012.

Lewis, A. C., Evans, M. J., Hopkins, J. R., Punjabi, S., Read, K. A., Purvis, R. M., Andrews, S. J., Moller, S. J., Carpenter, L. J., Lee, J. D., Rickard, A. R., Palmer, P. I., and Parrington, M.: The influence of biomass burning on the global distribution of selected non-methane organic compounds, Atmos. Chem. Phys., 13, 851-867, doi:10.5194/acp-13-851-2013, 2013.

Maanavilja, L., Riutta, T., Aurela, M., Pulkkinen, M., Laurila, T., and Tuittila, E.-S.: Spatial variation in $\mathrm{CO}_{2}$ exchange at a northern aapa mire, Biogeochemistry, 104, 325-345, doi:10.1007/s10533-010-9505-7, 2011.

Mays, K. L., Shepson, P. B., Stirm, B. H., Karion, A., Sweeney, C., and Gurney, K. R.: Aircraft-Based Measurements of the Carbon Footprint of Indianapolis, Environ. Sci. Technol., 43, 7816-7823, doi:10.1021/es901326b, 2009.

McMillen, R. T.: An eddy-correlation technique with extended applicability to non-simple terrain, Bound.-Lay. Meteorol., 43, 231-245, doi:10.1007/bf00128405, 1988.

Melton, J. R., Wania, R., Hodson, E. L., Poulter, B., Ringeval, B., Spahni, R., Bohn, T., Avis, C. A., Beerling, D. J., Chen, G., Eliseev, A. V., Denisov, S. N., Hopcroft, P. O., Lettenmaier, D. P., Riley, W. J., Singarayer, J. S., Subin, Z. M., Tian, H., Zürcher, S., Brovkin, V., van Bodegom, P. M., Kleinen, T., Yu, Z. C., and Kaplan, J. O.: Present state of global wetland extent and wetland methane modelling: conclusions from a model intercomparison project (WETCHIMP), Biogeosciences, 10, 753788, doi:10.5194/bg-10-753-2013, 2013. 
Miller, J. B., Gatti, L. V., d'Amelio, M. T. S., Crotwell, A. M., Dlugokencky, E. J., Bakwin, P., Artaxo, P., and Tans, P. P.: Airborne measurements indicate large methane emissions from the eastern Amazon basin, Geophys. Res. Lett., 34, L10809, doi:10.1029/2006g1029213, 2007.

Nisbet, E. G. and Chappellaz, J.: Shifting Gear, Quickly, Science, 324, 477-478, doi:10.1126/science.1172001, 2009.

Niu, G.-Y., Yang, Z.-L., Dickinson, R. E., and Gulden, L. E.: A simple TOPMODEL-based runoff parameterization (SIMTOP) for use in GCMs, J. Geophys. Res., 110, D21106, doi:10.1029/2005JD006111, 2005.

O’Connor, F. M., Boucher, O., Gedney, N., Jones, C. D., Folberth, G. A., Coppell, R., Friedlingstein, P., Collins, W. J., Chappellaz, J., Ridley, J., and Johnson, C. E.: Possible role of wetlands, permafrost, and methane hydrates in the methane cycle under future climate change: a review, Rev. Geophys., 48, RG4005, doi:10.1029/2010rg000326, 2010.

Oelke, C., Zhang, T. J., and Serreze, M. C.: Modeling evidence for recent warming of the Arctic soil thermal regime, Geophys. Res. Lett., 31, L07208, doi:10.1029/2003gl019300, 2004.

O'Shea, S. J., Allen, G., Gallagher, M. W., Bauguitte, S. J.-B., Illingworth, S. M., Le Breton, M., Muller, J. B. A., Percival, C. J., Archibald, A. T., Oram, D. E., Parrington, M., Palmer, P. I., and Lewis, A. C.: Airborne observations of trace gases over boreal Canada during BORTAS: campaign climatology, air mass analysis and enhancement ratios, Atmos. Chem. Phys., 13, 1245112467, doi:10.5194/acp-13-12451-2013, 2013a.

O'Shea, S. J., Bauguitte, S. J.-B., Gallagher, M. W., Lowry, D., and Percival, C. J.: Development of a cavity-enhanced absorption spectrometer for airborne measurements of $\mathrm{CH}_{4}$ and $\mathrm{CO}_{2}$, Atmos. Meas. Tech., 6, 1095-1109, doi:10.5194/amt-6-1095-2013, $2013 b$.

O'Shea, S. J., Allen, G., Fleming, Z. L., Bauguitte, S. J. B., Gallagher, M. W., Percival, C. J., Lee, J., Helfter, C., and Nemitz, $\mathrm{E}, .:$ Area fluxes of carbon dioxide, methane and carbon monoxide derived from airborne measurements around Greater London: A case study during Summer 2012, J. Geophys. Res, 119, 49404952, doi:10.1002/2013JD021269, 2014.

Parmentier, F. J. W., van Huissteden, J., Kip, N., Op den Camp, H. J. M., Jetten, M. S. M., Maximov, T. C., and Dolman, A. J.: The role of endophytic methane-oxidizing bacteria in submerged Sphagnum in determining methane emissions of Northeastern Siberian tundra, Biogeosciences, 8, 1267-1278, doi:10.5194/bg-8-12672011, 2011.

Parmentier, F.-J. W., Christensen, T. R., Sorensen, L. L., Rysgaard, S., McGuire, A. D., Miller, P. A., and Walker, D. A.: The impact of lower sea-ice extent on Arctic greenhouse-gas exchange, Nature Clim. Change, 3, 195-202, 2013.

Pataki, D. E., Ehleringer, J. R., Flanagan, L. B., Yakir, D., Bowling, D. R., Still, C. J., Buchmann, N., Kaplan, J. O., and Berry, J. A.: The application and interpretation of Keeling plots in terrestrial carbon cycle research, Global Biogeochem. Cy., 17, 1022, doi:10.1029/2001GB001850, 2003.

Peischl, J., Ryerson, T. B., Holloway, J. S., Trainer, M., Andrews, A. E., Atlas, E. L., Blake, D. R., Daube, B. C., Dlugokencky, E. J., Fischer, M. L., Goldstein, A. H., Guha, A., Karl, T., Kofler, J., Kosciuch, E., Misztal, P. K., Perring, A. E., Pollack, I. B., Santoni, G. W., Schwarz, J. P., Spackman, J. R., Wofsy, S. C., and Parrish, D. D.: Airborne observations of methane emissions from rice cultivation in the Sacramento Valley of California, J. Geophys. Res, 117, D00V25, doi:10.1029/2012jd017994, 2012.

Pelletier, L., Moore, T. R., Roulet, N. T., Garneau, M., and Beaulieu-Audy, V.: Methane fluxes from three peatlands in the La Grande Riviere watershed, James Bay lowland, Canada, J. Geophys. Res.-Biogeo., 112, G01018, doi:10.1029/2006jg000216, 2007.

Petrescu, A. M. R., van Huissteden, J., Jackowicz-Korczynski, M., Yurova, A., Christensen, T. R., Crill, P. M., Bäckstrand, K., and Maximov, T. C.: Modelling $\mathrm{CH}_{4}$ emissions from arctic wetlands: effects of hydrological parameterization, Biogeosciences, 5, 111-121, doi:10.5194/bg-5-111-2008, 2008.

Petrescu, A. M. R., van Beek, E. J. R., van Huissteden, J., Prigent, C., Sachs, T., Corradi, C. A. R., Parmentier, F. J. W., and Dolman, A. J.: Modeling regional to global $\mathrm{CH}_{4}$ emissions of boreal and arctic wetlands, Global Biogeochem. Cy., 24, GB4009, doi:10.1029/2009GB003610, 2010.

Pickett-Heaps, C. A., Jacob, D. J., Wecht, K. J., Kort, E. A., Wofsy, S. C., Diskin, G. S., Worthy, D. E. J., Kaplan, J. O., Bey, I., and Drevet, J.: Magnitude and seasonality of wetland methane emissions from the Hudson Bay Lowlands (Canada), Atmos. Chem. Phys., 11, 3773-3779, doi:10.5194/acp-11-3773-2011, 2011.

Ping, C.-L., Michaelson, G. J., Jorgenson, M. T., Kimble, J. M., Epstein, H., Romanovsky, V. E., and Walker, D. A.: High stocks of soil organic carbon in the North American Arctic region, Nat. Geosci., 1, 615-619, doi:10.1038/ngeo284, 2008.

Quiquet, A., Archibald A. T., Friend, A. D., Chappellaz, J., Levine, J. G., Stone, E. J., Telford, P. J., and Pyle, J. A.: The relative importance of methane sources and sinks during the Last Interglacial period, A, Quaternary Sci. Rev., in review, 2014.

Ridgwell, A. J., Marshall, S. J., and Gregson, K.: Consumption of atmospheric methane by soils: A process-based model, Global Biogeochem. Cy., 13, 59-70, doi:10.1029/1998gb900004, 1999.

Ryerson, T. B., Buhr, M. P., Frost, G. J., Goldan, P. D., Holloway, J. S., Hubler, G., Jobson, B. T., Kuster, W. C., McKeen, S. A., Parrish, D. D., Roberts, J. M., Sueper, D. T., Trainer, M., Williams, J., and Fehsenfeld, F. C.: Emissions lifetimes and ozone formation in power plant plumes, J. Geophys. Res.-Atmos., 103, 22569-22583, doi:10.1029/98jd01620, 1998.

Ryall, D. B. and Maryon, R. H.: Validation of the UK Met Office's NAME model against the ETEX dataset, Atmos. Environ., 32, 4265-4276, 1998.

Ryall, D. B., Maryon, R. H., Derwent, R. G., and Simmonds, P. G..: Modelling long-range transport of CFCs to Mace Head, Ireland, Q. J. Roy. Meteorol. Soc., 124, 417-446, 1998.

Schmidt, G. A., Ruedy, R., Hansen, J. E., Aleinov, I., Bell, N., Bauer, M., Bauer, S., Cairns, B., Canuto, V., Cheng, Y., Del Genio, A., Faluvegi, G., Friend, A. D., Hall, T. M., Hu, Y., Kelley, M., Kiang, N. Y., Koch, D., Lacis, A. A., Lerner, J., Lo, K. K., Miller, R. L., Nazarenko, L., Oinas, V., Perlwitz, J., Perlwitz, J., Rind, D., Romanou, A., Russell, G. L., Sato, M., Shindell, D. T., Stone, P. H., Sun, S., Tausnev, N., Thresher, D., and Yao, M.-S.: Present day atmospheric simulations using giss model: Comparison to in-situ, satellite and reanalysis data, J. Climate, 19, 153192, 2006.

Schuur, E. A. G., Vogel, J. G., Crummer, K. G., Lee, H., Sickman, J. O., and Osterkamp, T. E.: The effect of permafrost thaw on old carbon release and net carbon exchange from tundra, Nature, 459, 556-559, doi:10.1038/nature08031, 2009. 
Shakhova, N., Semiletov, I., Salyuk, A., Yusupov, V., Kosmach, D., and Gustafsson, O.: Extensive Methane Venting to the Atmosphere from Sediments of the East Siberian Arctic Shelf, Science, 327, 1246-1250, doi:10.1126/science.1182221, 2010.

Sriskantharajah, S., Fisher, R., Lowry, D., Aalto, T., Hatakka, T., Aurela, M., Laurila, T., Lohila, A., Kuitunen, E., and Nisbet, E.: Stable carbon isotope signatures of methane from a Finnish subarctic wetland, Tellus B, 64, 18818, doi:10.3402/tellusb.v64i0.18818, 2012.

Sitch, S., McGuire, A. D., Kimball, J., Gedney, N., Gamon, J., Engstrom, R., Wolf, A., Zhuang, Q., Clein, J., and McDonald, K. C.: Assessing the carbon balance of circumpolar Arctic tundra using remote sensing and process modelling, Ecol. Appl., 17, 213-234, doi:10.1890/1051-0761(2007)017[0213:atcboc]2.0.co;2, 2007.

Smith, L. C., MacDonald, G. M., Velichko, A. A., Beilman, D. W., Borisova, O. K., Frey, K. E., Kremenetski, K. V., and Sheng, Y.: Siberian peatlands a net carbon sink and global methane source since the early Holocene, Science, 303, 353-356, doi:10.1126/science.1090553, 2004.

Strom, L. and Christensen, T. R.: Below ground carbon turnover and greenhouse gas exchanges in a sub-arctic wetland, Soil Biol. Biochem., 39, 1689-1698, doi:10.1016/j.soilbio.2007.01.019, 2007.

Stull, R. B.: An Introduction to Boundary Layer Meteorology, Kluwer Academic Publishers, Dordrecht, 670 pp., 1988.

Vay, S. A., Choi, Y., Vadrevu, K. P., Blake, D. R., Tyler, S. C., Wisthaler, A., Hecobian, A., Kondo, Y., Diskin, G. S., Sachse, G. W., Woo, J. H., Weinheimer, A. J., Burkhart, J. F., Stohl, A., and Wennberg, P. O.: Patterns of $\mathrm{CO}_{2}$ and radiocarbon across high northern latitudes during International Polar Year 2008, J. Geophys. Res.-Atmos., 116, D14301, doi:10.1029/2011jd015643, 2011.

Viovy, N. and Ciais, P.: A combined dataset for ecosystem modelling, available at: http://dods.extra.cea.fr/store/p529viov/ cruncep/V4_1901_2012/ (last access: 10 July 2013), 2009.

Walter, K. M., Edwards, M. E., Grosse, G., Zimov, S. A., and Chapin, F. S., III: Thermokarst lakes as a source of atmospheric $\mathrm{CH}_{4}$ during the last deglaciation, Science, 318, 633-636, doi:10.1126/science.1142924, 2007.

Wania, R., Ross, I., and Prentice, I. C.: Implementation and evaluation of a new methane model within a dynamic global vegetation model: LPJ-WHyMe v1.3.1, Geosci. Model Dev., 3, 565-584, doi:10.5194/gmd-3-565-2010, 2010.
Webb, E. K., Pearman, G. I., and Leuning, R.: Correction of flux measurements for density effects due to heat and water vapour-transfer, Q. J. Roy. Meteor. Soc., 106, 85-100, doi:10.1002/qj.49710644707, 1980.

Westbrook, G. K., Thatcher, K. E., Rohling, E. J., Piotrowski, A. M., Paelike, H., Osborne, A. H., Nisbet, E. G., Minshull, T. A., Lanoiselle, M., James, R. H., Huehnerbach, V., Green, D., Fisher, R. E., Crocker, A. J., Chabert, A., Bolton, C., BeszczynskaMoeller, A., Berndt, C., and Aquilina, A.: Escape of methane gas from the seabed along the West Spitsbergen continental margin, Geophys. Res. Lett., 36, L15608, doi:10.1029/2009g1039191, 2009.

White, W. H., Anderson, J. A., Blumenthal, D. L., Husar, R. B., Gillani, N. V., Husar, J. D., and Wilson, W. E.: Formation and Transport of Secondary Air- Pollutants- Ozone and Aerosols in St-Louise Urban Plume, Science, 194, 187-189, doi:10.1126/science.959846, 1976.

Wratt, D. S., Gimson, N. R., Brailsford, G. W., Lassey, K. R., Bromley, A. M., and Bell, M. J.: Estimating regional methane emissions from agriculture using aircraft measurements of concentration profiles, Atmos. Environ., 35, 497-508, doi:10.1016/s13522310(00)00336-8, 2001.

Zhuang, Q., Melillo, J. M., Sarofim, M. C., Kicklighter, D. W., McGuire, A. D., Felzer, B. S., Sokolov, A., Prinn, R. G., Steudler, P. A., and $\mathrm{Hu}, \mathrm{S}$.: $\mathrm{CO}_{2}$ and $\mathrm{CH}_{4}$ exchanges between land ecosystems and the atmosphere in northern high latitudes over the 21st century, Geophys. Res. Lett., 33, L17403, doi:10.1029/2006g1026972, 2006.

Zimov, S. A., Davydov, S. P., Zimova, G. M., Davydova, A. I., Schuur, E. A. G., Dutta, K., and Chapin, F. S., III: Permafrost carbon: Stock and decomposability of a globally significant carbon pool, Geophys. Res. Lett., 33, L20502, doi:10.1029/2006g1027484, 2006a.

Zimov, S. A., Schuur, E. A. G., and Chapin, F. S.: Permafrost and the global carbon budget, Science, 312, 1612-1613, doi:10.1126/science.1128908, 2006b. 